Case Report

\title{
Understanding and Acceptance of Smart City Policies: Practitioners' Perspectives on the Malaysian Smart City Framework
}

\author{
Seng Boon Lim ${ }^{1} \mathbb{D}$, Jalaluddin Abdul Malek ${ }^{1}$, Md Farabi Yussoff Md Yussoff ${ }^{2}$ and Tan Yigitcanlar ${ }^{3,4, *(\mathbb{D})}$ \\ 1 Center for Research in Development, Social and Environment (SEEDS), \\ Faculty of Social Sciences and Humanities, University Kebangsaan Malaysia, Bangi 43600, Malaysia; \\ lims@ukm.edu.my (S.B.L.); jbam@ukm.edu.my (J.A.M.) \\ 2 Federal Government Administrative Centre, Federal Department of Town and Country Planning, \\ Ministry of Housing and Local Government, Putrajaya 62675, Malaysia; farabi@planmalaysia.gov.my \\ 3 School of Architecture and Built Environment, Queensland University of Technology, \\ Brisbane, QLD 4000, Australia \\ 4 School of Technology, Federal University of Santa Catarina, Campus Universitario, \\ Florianópolis 88040-900, SC, Brazil \\ * Correspondence: tan.yigitcanlar@qut.edu.au or tan.yigitcanlar@ufsc.br; Tel.: +61-7-3138-2418
}

Citation: Lim, S.B.; Malek, J.A.; Yussoff, M.F.Y.M.; Yigitcanlar, T. Understanding and Acceptance of Smart City Policies: Practitioners' Perspectives on the Malaysian Smart City Framework. Sustainability 2021, 13, 9559. https://doi.org/ 10.3390/su13179559

Received: 5 August 2021

Accepted: 23 August 2021

Published: 25 August 2021

Publisher's Note: MDPI stays neutral with regard to jurisdictional claims in published maps and institutional affiliations.

Copyright: (c) 2021 by the authors Licensee MDPI, Basel, Switzerland. This article is an open access article distributed under the terms and conditions of the Creative Commons Attribution (CC BY) license (https:/ / creativecommons.org/licenses/by/ $4.0 /)$.

\begin{abstract}
Whilst a plethora of research exists on the smart cities and project performance evaluations, only few studies have focused on the smart city policy evaluation from the perspective of its acceptance by practitioners. This paper aims to generate insights by evaluating the smart city policy through a developing country case study-i.e., Malaysia. This study employed a questionnaire survey method for data collection and analyzed the data by using Fuzzy Delphi analysis. A group of 40 practitioners was gathered in a focus group discussion through purposive sampling. The main objectives of this survey were to identify the understanding and acceptance levels of the seven smart city domains and respective strategies that are outlined in the Malaysian Smart City Framework. The results disclosed that the practitioners possessed divergent levels of understanding and acceptance in terms of smart city domains. The study participant practitioners accepted all understanding and acceptance objectives of smart economy, living, people, and governance domains (expert agreement 75-92\% and threshold $d$ value 0.123-0.188), but rejected all objectives for both smart environment and digital infrastructure domains (expert agreement $55-74 \%$ and threshold $d$ value $0.150-0.212$ ). Along with this, acceptance of smart mobility was also rejected (expert agreement $56 \%$ and threshold $d$ value 0.245 ). The findings reveal that considering all opinions expressing dissensus is essential when building more inclusive smart city strategies. This study contributes to the smart city discourse as being one of the first in capturing professional practitioners' understanding and acceptance on a national level smart city policy by applying the Delphi method in the smart city context. Most importantly, the study informs urban policymakers on how to capture the voices and perspectives of the general public on national and local smart city strategy and initiatives.
\end{abstract}

Keywords: Europe; Fuzzy Delphi method; Hong Kong; India; Malaysia; smart cities; smart city policy; smart urbanization; urban policy; policy evaluation

\section{Introduction}

Since the early 2000s, smart city development has been gaining global momentum. Thus, many models or concepts have been formed, adopted, and evaluated [1]. For example, the seminal smart city concept by [2] laid the basis for the formation of six smart city domains (i.e., smart economy, people, governance, mobility, environment, and living) and emphasized activities that would cultivate independent citizens. Since then, many models have been adopted and adapted from the concept of [2], such as the smart cities wheel by [3], the initiative framework of the smart city by [4], the alternative framework for 
smart city governance by [5], the conceptual framework for defining the smart city by [6], and the Unified Smart City Model by [7]. On the other hand, top-down smart policies that have been adopted and adapted from the work of [2] include the Hong Kong Smart City Blueprint [8] and the Malaysian Smart City Framework (MSCF) [9].

Furthermore, many studies have evaluated smart city performance. For instance, Ref. [2] developed the European medium-sized (smart) city indicators and ranking; Ref. [10] used the analytic network process (ANP) to investigate the relations between smart city domains, actors (i.e., government, industry, university, and civil society), and strategies; Ref. [11] examined the Malaysian smart city domains through the AHP; Ref. [12] developed a smart city descriptor scoring table to qualitatively compare smart city domains performance in Singapore, Korea, and Malaysia; Ref. [13] developed a smart city sharable framework to evaluate 17 smart cities in China; Ref. [14] developed a fuzzy synthetic evaluation of the challenges facing smart city development in developing countries; Ref. [15] developed a typology of smart city assessment tools and evaluated 122 cities; Ref. [16] developed the smart city index and ranking; and ref. [17] recently developed a smart city measurement framework for inclusive growth.

Nevertheless, far less research has been conducted on evaluating the smart city policy, with the exception of scholars such as [18], who made a general evaluation of the smart city policy and the challenges facing five UK cities. It is crucial to evaluate each planned top-down policy, especially from the public perspective. With just internal assessments by the authorities and departments, actual situations and shortfalls may be overlooked. This might result in overall failure and wasted investment and resources. Taking the case of the MSCF, launched in 2019, to date there have been no evaluation reports on the strategies being planned. Furthermore, the period from 2021 to 2022 has been scheduled as the time to implement smart initiatives nationwide [9]. Many local authorities lack suitable references and benchmarking on the details of the smart city domains and strategies to be adopted [19]. Without reference to evaluation, authorities or officers on the ground tend to believe that a blueprint is perfect and will follow it to the letter. Thus, in this research, and given the practical knowledge gaps, the authors intend to answer the following questions:

- What level of understanding do practitioners have of the smart city domains stated in MSCF?

- What level of acceptance do practitioners have of the smart city domains stated in MSCF?

Based on these research questions, this study aims to evaluate the understanding and acceptance of practitioners from various sectors who are involved in smart city development in developing countries (using Malaysia as a case study). Knowing the levels of public understanding and acceptance was intended to be the output of this study, which would thus provide guidance to governments and policymakers to improve the smart city strategies and policies so that more smart and inclusive living is available to their citizens.

\section{Literature Background}

Understanding the basic smart city domains is mainly influenced by the six domains outlined by [2], namely the smart economy, living, environment, people, governance, and mobility.

According to [2], the smart economy component is characterized by competitiveness. Among the sub-components of the smart economy (in the case of medium-sized European city rankings) are an innovative spirit, entrepreneurship, an economic image and trademark, productivity, labor market flexibility, and international embeddedness. As the economy is a broad concept and its strategies are context-based, many scholars and agencies have suggested measuring specific components, including nineteen economic attributes in the case of India, as stated by [20]. These include promoting balanced and sustainable economic growth, making strategic investments on strategic assets, and knowing that all forms of economics function at the local level. In another case, the smart economy domain of the 
Hong Kong Smart City Blueprint [8] promotes sharing economy, fintech, smart tourism, and re-industrialization.

In the case of Malaysia, the components stated in MSCF are to intensify the application of technology and digitalization in core business functions, enhance the usage of e-payment, attract investment in high value-added industries, create a workforce to match the jobs in these industries, provide technology labs and collaborative platforms, establish incubators and accelerators, and leverage existing government assistance and funding. Supporting literature can be found in Table 1.

Table 1. Smart economy domain.

\begin{tabular}{cc}
\hline Smart Economy Strategy & Reference \\
\hline Intensify technology application and digitalization in core business functions & {$[2,20-22]$} \\
Enhance the usage of e-payment & {$[23-25]$} \\
Attract investment in high value-added industries & {$[26,27]$} \\
Create workforce to match jobs in high value-added industries & {$[4,28,29]$} \\
Provide technology labs and collaborative platforms & {$[22,30,31]$} \\
Establish incubators and accelerators & {$[32,33]$} \\
Leverage on existing government assistance and funding & {$[20,30]$} \\
\hline
\end{tabular}

High value-added activities refer to the major contribution of a private industry or government sector to overall gross domestic product (GDP) [34]. Contributions to GDP include higher wages and compensation for employees, taxes on production, lower import subsidies, and a gross operating surplus [34]. The Hong Kong labor market is an example of a concentration of high value-added service industries, with $25.9 \%$ of employees working in public administration or in the social and personal services industry in 2014 [35]. However, it is challenging to transition from low to high value-added industries in developing countries. This is the case in Indonesia, where low value-added industries such as textiles are desperately fighting rising wages and seeking protection from international competition. High value-added sectors largely utilize technology in various activities, including designing products, delivering products, processing customer orders, and improving product quality [27]. Nevertheless, according to MSCF, technology disruptors in Malaysia, such as robotics and analytics, are shifting traditional services towards value-adding and non-traditional service areas. However, the authors observed that MSCF did not refer to the issues of wages and imbalanced urban-rural development. Correspondingly, the smart city policy has offered opportunities within the Fourth Industrial Revolution (Industry 4.0) mostly in developed states and urban areas, while less-developed states and rural areas, such as Sabah, are mentioned far less.

The second domain of smart living is characterized by the quality of life. Among the sub-components found in the smart living concept outlined by [2] are cultural facilities, health conditions, individual safety, housing quality, educational facilities, touristic attractivity, and social cohesion. In the Indian case, [20] scoped smart living into 14 attributes, including promoting shared values in society, celebrating local history and culture, and opening highly accessible public spaces. In the case of Hong Kong, their strategies are in building a Wi-Fi-connected city, developing faster digital payment systems, providing free electronic identity (eID) citizenship for government and commercial online transactions, and launching a $\$ 1$ billion funding scheme to support the procurement of technological products by elderly and rehabilitation service units [8].

In Malaysia, the MSCF strategies are to enhance safety and security, promote the provision of quality housing, optimize emergency responses, enhance the quality of healthcare services through digital technology and encourage urban farming for better living. Supporting literature can be found in Table 2. 
Table 2. Smart living domain.

\begin{tabular}{cc}
\hline Smart Living Strategy & Reference \\
\hline Enhance safety and security & {$[20,36,37]$} \\
Promote quality housing & {$[2,38]$} \\
Optimize emergency response & {$[20,39]$} \\
Enhance quality of healthcare services through digital technology & {$[40-43]$} \\
Encourage urban farming for better living & {$[23,44]$} \\
\hline
\end{tabular}

Concerning the element of enhancing safety and security, one key initiative in Malaysia is the focus on crime reduction $[36,45]$. For example, under the safe city initiative through the Ministry of Housing and Local Government, a safer city can be created using several strategies, such as crime prevention through environmental design (CPTED) and crime prevention through social design (CSPD) [46]. With CPTED, information and communication technology (ICT), and mechanical surveillance design initiatives are popular, including the installation of closed-circuit television (CCTV) in public spaces, IoT (internet-of-things) lighting, safety (panic button) alarms, and establishing GIS (geographic information system) mapping for crime detection [36]. In the case of the capital city, Kuala Lumpur, crime is always an important issue for the citizens and the city authorities. Research has shown that the challenges to making Kuala Lumpur a safe city can be mitigated by enhancing the role of guardians (i.e., the authorities); promoting CPTED and CSPD activities; and assisting victims and offenders with psychological, financial, and family assistance [47].

The idea behind the third domain, smart environment, centers on preserving natural resources. The smart environment sub-components outlined by [2] are the attractivity of natural conditions, pollution, environmental protection efforts, and sustainable resource management. Another source of reference from India, Vinod Kumar [20], presented 22 attributes to describe the smart environment, which included protecting nature; managing water resources, water supply systems, floods, and inundations effectively; encouraging neighborliness and a spirit of community; upgrading urban resilience to the impacts of climate change; and creating a low-carbon environment based on energy efficiency, renewable energy, and the like. In the Hong Kong case, the strategies are focused on reducing the carbon intensity; promoting energy efficiency and conservation in the community, with a particular focus on green and intelligent buildings; reducing waste; and monitoring the air pollution and cleanliness of public spaces [8].

In Malaysia, MSCF smart environment strategies include the need to preserve green areas and enhance the management of trees in public parks; strengthen the integrated and sustainable solid waste management; strengthen the solid waste laws and policies; improve the air quality and its monitoring system; improve the water quality and its monitoring system; increase energy efficiency and promote renewable energy sources in the community; enhance disaster risk management by adopting advanced technology applications; enhance the non-revenue water management; and encourage the development of a low-carbon city concept that can be adopted at the local level. Supporting literature can be found in Table 3 .

Table 3. Smart environment domain.

\begin{tabular}{|c|c|}
\hline Smart Environment Strategy & Reference \\
\hline Preserve green area and enhance the management of trees in public parks & {$[2,48]$} \\
\hline Strengthen the integrated and sustainable solid waste management & {$[2,48]$} \\
\hline Strengthen the solid waste laws and policies & {$[49,50]$} \\
\hline Improve the air quality and its monitoring system & {$[50,51]$} \\
\hline Improve the water quality and its monitoring system & {$[2,50]$} \\
\hline Increase energy efficiency and promote renewable energy sources in community & {$[2,20,37]$} \\
\hline Enhance the disaster risk management by adopting advanced technology application & {$[52,53]$} \\
\hline Enhance the non-revenue water management & {$[2,54]$} \\
\hline Encourage the development of low carbon city concept to be adopted at local level & {$[48,55]$} \\
\hline
\end{tabular}


In terms of park and green area management, the reduction in size of reserved forest and the preservation of green space in development plans are continual issues in Malaysia. Although forest land may have been gazetted, new development plans have always resulted in excuses to degazette forest reserves in favor of mixed-use development. For example, the Selangor State Government has recently granted a mixed development project on 931 hectares of the Kuala Langat North Forest Reserve, which is largely a move to rescind the protected status of the remnants of a once-sprawling peat forest that has been home to four indigenous Temuan settlements. The project also threatens wildlife [56]. This is one case that demonstrates the image of the Malaysian government, which can easily override gazetted land protection with the introduction of new plans under political influence and with profitable intentions, despite concerns for the public good of civil society, climate change, and the overall environment.

In terms of community attitudes to environmental protection, much change is required in Malaysia, especially within the authority-dependence mindset. The study on the Iskandar territory, Johor, Malaysia, Ref. [57] showed that residents are conscious of the need for environmental cleanliness; however, their mindsets were hindered by the belief that the cleanliness of public space is mainly the responsibility of the authorities. Thus, Ref. [57] reaffirmed that the involvement and accountability of all parties are much needed in caring for the natural environment.

The fourth domain of smart people is characterized by social and human capital [2]. The indicators for the case of Europe include the level of qualification, affinity with lifelong learning, social and ethnic plurality, flexibility, creativity, cosmopolitanism, openmindedness, and participation in public life. In the case of India, 'smart people' are proposed as being the fundamental building block of a smart city system because, without people's active participation, a smart city system would not function effectively (Figure 1). Thus, Ref. [20] proposed eleven attributes of smart people by including the need to be actively involved in the city's sustainable development; excel in creativity and finding unique solutions to challenging issues; opt for lifelong learning and use e-learning models; and be cosmopolitan and open-minded and hold a multicultural perspective. In the case of Hong Kong, this focuses on nurturing young talent, innovation, and entrepreneurial culture [8].

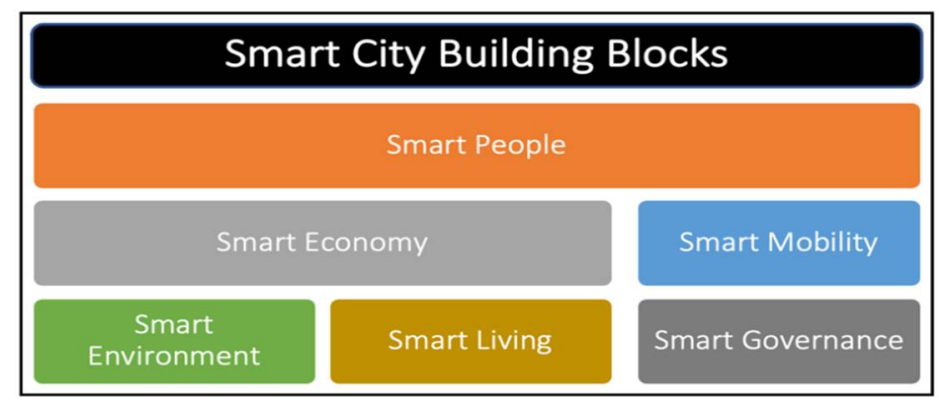

Figure 1. Smart city system building blocks, adapted from [20].

In the case of Malaysia, the strategies are to improve moral education in schools; enhance public awareness in practicing good moral and civic duties; increase skilled and talented human capital at every level; enhance public participation and community empowerment initiatives; improve gender sensitization and the inclusivity of vulnerable groups; and increase public willingness to adapt to emerging technologies. Supporting literature can be found in Table 4. 
Table 4. Smart people domain.

\begin{tabular}{cc}
\hline Smart People Strategy & Reference \\
\hline Improve moral education in schools & {$[58,59]$} \\
Enhance public awareness in practicing good moral and civic & {$[59,60]$} \\
Increase skilled and talented human capital at every level & {$[8,20]$} \\
Enhance public participation and community empowerment initiatives & {$[20,61-63]$} \\
Improve gender sensitization and inclusivity of vulnerable groups & {$[52,64]$} \\
Increase the public willingness to adapt with emerging technologies & {$[8,20,65]$} \\
\hline
\end{tabular}

The element of cultivating skilled and talented human capital is particularly crucial, as Malaysia is determined to adopt the National Fourth Industrial Revolution Policy (Malaysian Industry 4.0 Policy), which was launched recently on 1 July 2021 [66]. This Industry 4.0 policy was launched with the purpose of transforming Malaysia into a highincome state through technology and digitalization. Five fundamental technologies of the Industry 4.0 policy include artificial intelligence, the internet of things, blockchain, cloud computing and big data analytics, and advanced materials and technologies [67]. For the young generation to master these Industry 4.0 skills, it is crucial to plan every level of education properly. The Industry 4.0 policy is aligned with the Shared Prosperity Vision 2030, launched in 2019. The aim is to drive Malaysia towards developed nation status by 2030 .

The moral and spiritual education element is considered appropriate for the majority Muslim society in Malaysia. The moral element of cultivating smart people is comparatively silent in most western European smart societies (refer to [2,68]). Since the early 1980s, Royal Professor Ungku Abdul Aziz bin Ungku Abdul Hamid, a well-known academician in Malaysia, has creatively interpreted a religious and moral form of development, which represents a balance between the spiritual and material world and is geared towards the needs of the local Muslim community [59]. The emphasis on the moral and spiritual element adopted in the MSCF will further strengthen the quality of Malaysian citizenship by developing a more peaceful and caring society.

Citizen participation and community empowerment are often identified as important elements in realizing a citizen-centric smart city [20,62]. However, this attention should never be blinded by political actions that assume that tokenism and non-participation (refer to [61]) satisfy this type of participation. On the contrary, it is vital to involve citizens in decision making and agenda setting in the smart city initiatives [69].

The core value of the fifth domain of smart governance is political participation. From the European perspective, Ref. [2] described smart governance using the components of participation in decision making, public and social services, and transparent governance. The systematic literature review by [70] summarized six attributes for building a smart governance system. It should be based on ICT, external collaboration and participation, internal coordination, decision-making processes, e-administration, and outcomes. Prior research also suggests that the main outcome of smart city governance is the production of a wide range of public values through innovative collaborations [70].

From the Indian perspective, Ref. [71] suggested 12 steps to convert existing egovernance to smart governance, including an increase in city expenditure on ICT; the ease of access to e-services such as lodge complaints, claims and rights to information; and the promotion of e-democracy through e-decision making and e-voting. From the Hong Kong perspective, smart governance is promoted through using open data for smart city innovations; building smarter city infrastructure, such as the fifth generation (5G) mobile network; building a new big data analytics platform; data sharing among government departments; and adopting building information modelling (BIM) for major government capital work projects [8].

From the MSCF perspective, the components include increasing the scope of egovernment services, increasing the quality of e-government services, elevating the use of data sharing platforms across government agencies, and promoting information disclosure 
and open data from the Government. Table 5 shows the smart governance strategies in MSCF and the related citations.

Table 5. Smart governance domain.

\begin{tabular}{cc}
\hline Smart Governance Strategy & Reference \\
\hline Increase the scope of e-government services & {$[64,71,72]$} \\
Increase the quality of e-government services & {$[2,40,71,73]$} \\
Elevate the use of data sharing platform across government agencies & {$[26,70,74,75]$} \\
Promote information disclosure and open data from government & {$[8,76-79]$} \\
\hline
\end{tabular}

It is crucial to be aware of the component of elevating the use of data sharing platforms across government agencies, as the isolated performance of government agencies was identified by the former prime minister as hindering the performance and services of government agencies [80]. In fact, this lack of efficiency, which is due to excessive bureaucracy, the reluctance of public servants to share data, and other factors, is not a new issue in the delivery of the Malaysian government system [81,82].

Concerning the sixth domain, smart mobility, the main concerns outlined by [2] were transport and ICT. The sub-components of [2] include local accessibility; (inter)national accessibility; the availability of an ICT infrastructure; and sustainable, innovative, and safe transport systems. In the case of India, Ref. [20] described smart mobility in terms of ten attributes, such as a focus on the mobility of people but not vehicles; advocating walkability and cycling; balanced transportation options such as a mass rapid transit system; and seamless mobility for differently abled people. In the Hong Kong case, the strategies are to focus on intelligent transport systems and traffic management; public transport interchanges / bus stops and parking; environmental friendliness in transport; and smart airports with facial biometric technology. These features should offer a hassle-free travel experience [8].

In the Malaysian case, the smart mobility strategies address the need to establish intelligent transport management; enhance data sharing and digital mobility platforms; establish demand-based ridesharing services; utilize AI and the sensor-based predictive maintenance of a public transport fleet and infrastructure; enhance the dynamic smart parking infrastructure; establish an electric vehicle revolution; enhance collaboration with academia on research and development (R\&D) into, and the commercialization of, EVs and next-generation automobiles; and promote the usage of public transport applications. Table 6 shows the smart mobility strategies in MSCF and the related citations.

Table 6. Smart mobility domain.

\begin{tabular}{|c|c|}
\hline Smart Mobility Strategy & Reference \\
\hline Establish intelligent transport management & {$[2,8,20]$} \\
\hline Enhance data sharing and digital mobility platform & {$[83,84]$} \\
\hline Establish demand-based ride sharing services & {$[8,20,85]$} \\
\hline Utilize AI and sensor-based predictive maintenance of public transport fleet and infrastructure & {$[2,22,43,85,86]$} \\
\hline Enhance dynamic smart parking infrastructure & {$[8,43,83]$} \\
\hline Establish electric vehicle revolution & {$[85,87]$} \\
\hline $\begin{array}{l}\text { Enhance collaboration with academia on R\&D and commercialization on EVs and next-generation } \\
\text { automobile }\end{array}$ & {$[83,85]$} \\
\hline Promote the usage of public transport application & {$[8,83-85]$} \\
\hline
\end{tabular}

In general, all the components and strategies in various countries discussed above indicate that smart mobility is universal, regardless of whether it is introduced in the global north or south. The common item is the promotion of people-centric (rather than vehicle-centric) [83] and environmentally friendly (rather than utility convenient) transportation means [84]. The measures involved include opting to cycle and walk and to take public transport in the city rather than using a personal vehicle that produces greenhouse gas, carbon emissions, and pollution. This is predominantly important in many Asian cities; for example, Kuala Lumpur is characterized by heavy car dependence, leading to 
traffic congestion and delays [85]. Planning for future mobility must focus less on building more highways and being car-dependent but rather on alternative ways of thinking about environmentally friendly mobility means and adoption. Considering the need for environmental protection and the preference for connecting two destination points via electronic platforms/communication, the actual physical cost of travelling could be reduced.

In addition to the above six basic domains, the authors would like to discuss another emerging domain, that of smart digital infrastructure. This domain did not appear as an individual domain in [2,8,20]. Giffinger et al. [2] explicitly merged this element into the smart mobility domain. Meanwhile, in the case of Hong Kong, this digital infrastructure is explained/inserted in the smart government domain. As digital infrastructure is a frequent practice in Western and developed countries in Europe and North America, it is quite ready and more embedded into other domains. Under the New York Smart and Equitable City Plan 2015, digital infrastructure was embedded in the domains of smart buildings and infrastructure; smart transport and mobility; smart energy and environment; smart public health and safety; and smart government and community [88]. All the sectors and strategies within the smart cities concept center on ICT infrastructure, a point on which the authors and the majority of smart city scholars agree (Figure 2).

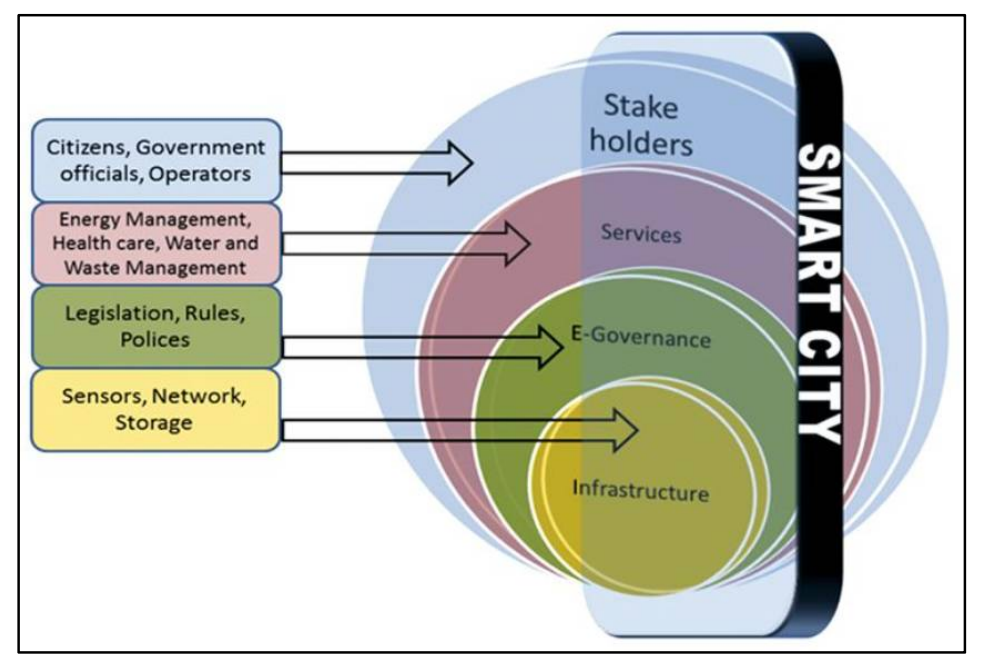

Figure 2. Digital infrastructure is the heart of smart city development [89].

However, in most private sectors conceptions, due to the propagation and sale of their latest technologies, this digital infrastructure element is explicitly highlighted. In the case of Frost and Sullivan, it is even divided into two different domains: smart technology and smart infrastructure (Figure 3).

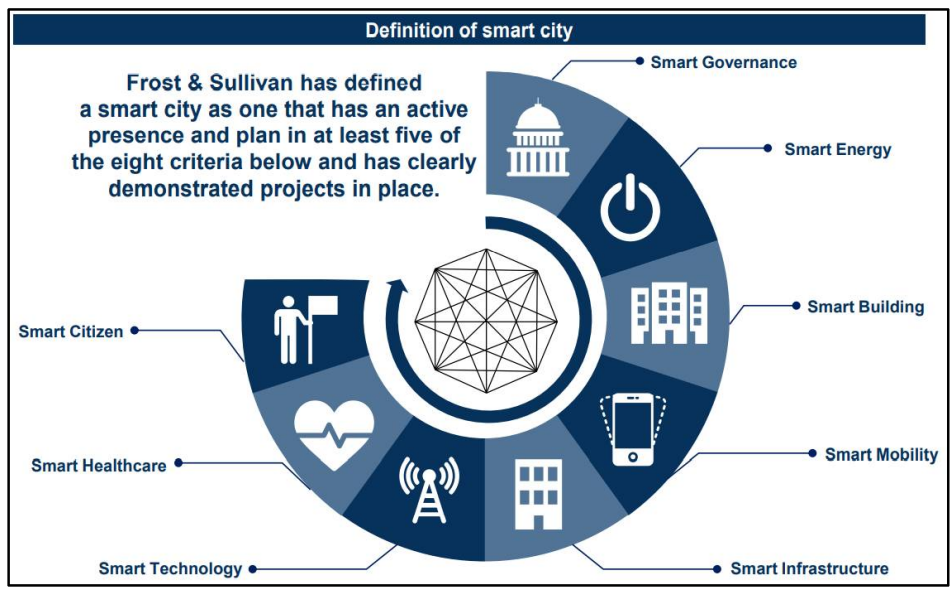

Figure 3. Smart city domains [90]. 
In MSCF, smart digital infrastructure has been designated as a separate seventh domain. The smart digital infrastructure strategies include the need to enhance the roles of service providers in developing digital infrastructure; enhance internet speed and connectivity; enhance the government's role in facilitating the development of communication infrastructure; enhance indoor and outdoor network coverage; strengthen policies related to personal data protection; and strengthen policies related to cybersecurity. Table 7 illustrates the strategies of the smart digital infrastructure domain and its related citations.

Table 7. Smart digital infrastructure domain.

\begin{tabular}{cc}
\hline Smart Digital Infrastructure Strategy & Reference \\
\hline Enhance service provider's role in developing digital infrastructure & {$[8,37,90,91]$} \\
Enhance internet speed and connectivity & {$[90,92]$} \\
Enhance government's role in facilitating the development of & {$[8,70,93]$} \\
communication infrastructure & {$[2,94,95]$} \\
Enhance indoor and outdoor network coverage & {$[96-98]$} \\
Strengthen policies related to personal data protection & {$[8,37,89,99,100]$} \\
Strengthen policies related to cybersecurity &
\end{tabular}

One form of digital infrastructure to attract attention in smart city development is the IoT. Using the internet, the IoT is a network that interconnects ordinary physical objects, such as smartphones, with identifiable addresses to provide intelligent services [101]. In 2021, 35 billion IoT devices were expected to be installed and there were 46 billion connected devices around the world [102]. These numbers, in total, represent more than ten times the size of the world population. Therefore, it could be imagined that it is crucial to tackle the cybersecurity issues that relate to using IoT machines and to address the need for personal data protection as part of living in smart cities. In Malaysia, cybersecurity cases rose by $82.5 \%$ between 18 March and 7 April 2020 (838 cases), compared to the same timeframe in 2019 (459 cases) [103]. These cases include some form of cyberbullying; fraud or intruding into an unauthorized system such as phishing and email scams; data breaches and distributed denial of service (DDoS) attacks on local businesses; and hacking into private video conferencing chats and harassing the participants during the COVID-19 movement control period.

To tackle these cybersecurity problems in combination with promoting IoT adoption, in 2015, the National IoT Strategic Roadmap was launched by the Ministry of Science, Technology, and Innovation, with the national applied R\&D center MIMOS Bhd. as the implementation secretariat and with the support of agencies such as Cybersecurity Malaysia [104]. This roadmap targeted the contribution of RM 9.3 billion (about USD 2.2 billion) to the gross national income and the creation of more than 14,000 highly skilled employment opportunities by 2020. In addition, other policies have been initiated, such as the National Industry 4.0 policy, the National Cyber Security Policy, and the Malaysia Personal Data Protection Act 2010. MSCF mentioned the need to review and enforce stronger laws, as well as upgrade security systems and procedures in the public and private sectors. In this context, cybersecurity has been identified as a policy to be strengthened in the smart city context.

\section{Methodology}

After outlining the smart city domains and examples of smart city policies worldwide, this methodology section explains the MSCF case study, the samples of respondents, the data collection, the questionnaire design, and the data analysis method.

\subsection{The Case of Malaysian Smart City Framework}

MSCF is the first top-down document to formulate the direction of smart city development in Malaysia. The document was launched in September 2019 and drafted by the Ministry of Housing and Local Government. In MSCF, smart cities are defined as "cities 
that use ICT and technological advancement to address urban issues, including to improve quality of life, promote economic growth, develop a sustainable and safe environment and encourage efficient urban management practices" [9]. This definition, in practice, aims to achieve the vision of "quality and smart living" [9].

In terms of planning, the implementation of smart cities nationwide is divided into three phases from 2019 to 2025 . These are phase 1 (the foundation stage), from 2019 to 2020 (two years); phase 2 (the development stage), from 2021 to 2022 (two years); and phase 3 (the advanced development and monitoring stage), from 2023 to 2025 (three years). To ensure its effective implementation, understanding, and acceptance among the people must also be investigated, especially for urban residents. Hence, this study focuses on the understanding and acceptance among professionals of MSCF. The study has been developed to identify the appropriateness of the outlined strategies.

As discussed previously, various components/strategies can be found in academic and grey literature under the grouping of each smart city domain, all of which depends on managing problems and challenges in local contexts. The case is the same in Malaysia, where the government had customized the domains, components, and strategies according to the local challenges. Based on the planned domains, 90 questionnaire items were designed (see Appendix A) and face validated by two smart city experts.

\subsection{Sampling and Data Collection}

This study employed a quantitative survey via the Fuzzy Delphi method. In obtaining expert opinions using the Fuzzy Delphi method, the ideal sample size is between 10 and 50 respondents $[105,106]$. Therefore, the authors decided to sample 40 smart city practitioners from the Kuala Lumpur Greater Valley area, including the city of Kuala Lumpur, Putrajaya, and Cyberjaya (Table 8).

Table 8. Informant sampling.

\begin{tabular}{|c|c|c|}
\hline Characteristic & Quantity $(N=40)$ & Percentage $(\%)$ \\
\hline \multicolumn{3}{|l|}{ Gender } \\
\hline Male & 19 & 47.5 \\
\hline Female & 21 & 52.5 \\
\hline \multicolumn{3}{|l|}{ Age } \\
\hline $23-30$ years old & 1 & 2.5 \\
\hline $31-40$ & 24 & 60.0 \\
\hline $41-50$ & 13 & 32.5 \\
\hline 51 years old and above & 2 & 5.0 \\
\hline \multicolumn{3}{|l|}{ Race } \\
\hline Malay & 36 & 90.0 \\
\hline Chinese & 2 & 5.0 \\
\hline Bumiputera Sabah and Sarawak & 2 & 5.0 \\
\hline \multicolumn{3}{|l|}{ Academic qualification } \\
\hline Bachelor's degree & 26 & 65.0 \\
\hline Master's degree & 8 & 20.0 \\
\hline PhD & 6 & 15.0 \\
\hline \multicolumn{3}{|l|}{ Employment sector } \\
\hline Government & 32 & 80.0 \\
\hline Private & 4 & 10.0 \\
\hline Self-employed & 4 & 10.0 \\
\hline \multicolumn{3}{|l|}{ Work experience } \\
\hline 5 to 8 years & 4 & 10.0 \\
\hline 9 to 10 years & 8 & 20.0 \\
\hline 11 to 15 years & 13 & 32.5 \\
\hline 16 to 20 years & 8 & 20.0 \\
\hline 21 years and above & 7 & 17.5 \\
\hline \multicolumn{3}{|l|}{ Job Position } \\
\hline Director/CEO & 12 & 25.5 \\
\hline Assistant director/Senior officer & 10 & 21.3 \\
\hline Executive officer & 8 & 17.0 \\
\hline Engineer/Planner/Architect & 14 & 29.8 \\
\hline Technician & 3 & 6.4 \\
\hline
\end{tabular}


As Table 8 shows, this group of practitioners consisted of those in the government, private, and self-employed sectors. They represented the middle class and various professional job roles, such as director/CEO, assistant director/senior officer, executive officer, engineer/planner/architect, and technician. Since the 1970s, the middle class has emerged as a significant group contributing to the urbanization process in major cities in Malaysia [107]. Thus, the selection of professionals as respondents was significant given the composition of this group, the majority of whom lived in urban areas. The professionals were selected based on various criteria: they had to have a minimum of five-year work experience; possess at least a bachelor's degree; and be primarily involved in the planning, design, delivery, and management of cities and their development.

The success of the Fuzzy Delphi method depends on the insights and information supplied by experts. Thus, a panel of experts/respondents was identified through a purposive sampling and nomination process, rather than random selection. Later, a focus group discussion was organized, and data were collected.

\subsection{Questionnaire Design}

Through a structured questionnaire, a survey strategy of enquiry was conducted. Three sections were used in the questionnaire to obtain information from the respondents. Section one was designed to determine the respondent's background. Section two focused on their understanding, while section three focused on their acceptance of the MSCF's domains. The questionnaire adopted a closed-ended design. The respondents were asked to rate the 90 variables based on their level of significance using a five-point Likert scale, with five being Strongly Agree and one being Strongly Disagree. For the details of the survey items, see Appendix A. Aghimien et al. [14] adopted a similar approach in their study that evaluated the challenges facing smart cities.

\subsection{Data Analysis}

In addition, the Fuzzy Delphi method was chosen as the analysis technique to obtain the agreement of experts, namely the professionals, based on the study objectives. The Fuzzy Delphi method is a Delphi method performed to obtain information regarding consensus on measurement variables or factors from a group of experts [108,109]. The Delphi Method has been shown to be effective in publishing the best ideas/views through collective responses from expert informants [110]. With the principle of "more minds are better than a single mind", the Fuzzy Delphi method is designed as a forecasting tool to gather the ideas of structured groups, which are said to be more accurate than unstructured predictions [111]. This technique allows experts to coordinate their actions systematically in addressing a particular problem or difficulty and reach a consensus.

In this study, expert consensus was evaluated based on the seven MSCF domains, namely the smart economy, smart living, smart environment, smart people, smart government, smart mobility, and smart digital infrastructure. Each of these domains has its own strategic initiatives to enable cities in Malaysia to achieve smart city status. Respondents' understanding and acceptance were analyzed to achieve the objectives of the study.

Questionnaire data obtained from the focus group feedback of professionals were analyzed using a formulated Microsoft Excel worksheet by [106]. The experts' score inputs were evaluated in stages. Mathematical scores-the Likert scale and the triangular fuzzy scale scores for each item-were obtained (Table 9) and converted into mean values. Later, the threshold value $(d)$, the percentage of expert agreement and the "defuzzification" process of the fuzzy score with $\alpha$-cut value were calculated. Finally, based on the above three criteria, the ranking positions of the consensus items accepted/rejected by the expert panel were analyzed. 
Table 9. Triangular fuzzy number scale [106].

\begin{tabular}{|c|c|c|c|c|c|c|c|c|c|c|c|c|c|c|c|}
\hline & \multicolumn{3}{|c|}{ Strongly Disagree } & \multicolumn{3}{|c|}{ Disagree } & \multicolumn{3}{|c|}{ Moderately Agree } & \multicolumn{3}{|c|}{ Agree } & \multicolumn{3}{|c|}{ Strongly Agree } \\
\hline Likert scale & & 1 & & & 2 & & & 3 & & & 4 & & & 5 & \\
\hline $\begin{array}{l}\text { Triangular fuzzy } \\
\text { Delphi scale }\end{array}$ & 0.0 & 0.0 & 0.2 & 0.0 & 0.2 & 0.4 & 0.2 & 0.4 & 0.6 & 0.4 & 0.6 & 0.8 & 0.6 & 0.8 & 1.0 \\
\hline
\end{tabular}

In detail, let us say the item "I am ready to use e-payment in my daily affairs" was scored 5 (strongly agree) by an expert. The score is converted into the minimum, most plausible, and maximum values of $0.6,0.8$, and 1.0 fuzzy scores. It indicated the expert is agreeable to the item is $60 \%, 80 \%$, and $100 \%$, respectively. Then, the fuzzy scale of $(0.6,0.8$, $1.0)$ is converted into mean value $(\bar{m})$ among the 40 responds.

Next, according to [112], the calculation of the threshold $(d)$ value performed was as follows:

$$
d(\bar{m}, \bar{n})=\sqrt{\frac{1}{3}\left[\left(m_{1}-n_{1}\right)^{2}+\left(m_{2}-n_{2}\right)^{2}+\left(m_{3}-n_{3}\right)^{2}\right]}
$$

where,

$d=$ the threshold value,

$m_{1}=$ the smallest mean value of a fuzzy number,

$m_{2}=$ the most plausible mean value of a fuzzy number,

$m_{3}=$ the maximum mean value of a fuzzy number,

$n_{1}=$ the smallest value of a fuzzy number,

$n_{2}=$ the most plausible value of a fuzzy number, and

$n_{3}=$ the maximum value of a fuzzy number.

The value of ' $d$ ' (the threshold value) for all items of the questionnaire indicates expert consensus agreement for each item. According to [112], the value of ' $d$ ' must be greater than or equal to 0.2 to indicate consensus agreement for each item.

For the expert agreement/consensus percentage, if the expert consensus exceeded $75 \%$, it was considered accepted $[113,114]$. Then, through the process of defuzzification or the process of determining the scores, the ranking positions of each item were determined. The formula used to determine the ranking/score for an item was as follows:

$$
A_{\max }=\frac{1}{3}\left(m_{1}+m_{2}+m_{3}\right)
$$

After an assessment was made, if the fuzzy $\left(A_{\max }\right)$ score or $\alpha$-cut value was equal to or exceeded 0.5, this indicated expert consensus to accept the item [115].

The Delphi method is a widely accepted, efficient, and effective way of bringing together experts to discuss, debate, and organize a body of information in order to develop a validated instrument, reach agreement on an issue, uncover common factors, or forecast trends $[116,117]$. This method is deemed particularly highly reliable when more than ten experts in the given field were employed $[105,106]$. Additionally, to minimize the bias, it is important to involve experts in a study that possess extensive experience, high qualifications, and knowledge in the field or the subject matter [118]. Evidently, this study meets these requirements as it has involved 40 experts with a minimum of five-year work experience, possessed at least a bachelor's degree, and involved intensively in the planning and management of smart cities in the context of Malaysia (Table 8). Hence, we did not employ an additional validation mechanism for the generated results of the Delphi study.

\section{Results}

In general, the understanding and acceptance of the targeted group of experts in this study were contested. This shows that the community has different perceptions of the smart city domains stated in the MSCF. This divergent phenomenon can be described in two ways. Firstly, from the domain perspective, the majority of domains (i.e., smart economy, 
living, people, and governance) were accepted, two domains (i.e., smart environment and digital infrastructure) were rejected, while the smart mobility domain was partially accepted. Secondly, from the objective perspective, more than half of the domains were accepted (Table 10).

Table 10. Results of Fuzzy Delphi analysis by smart city domains.

\begin{tabular}{|c|c|c|c|c|c|c|c|c|c|c|}
\hline \multirow[t]{2}{*}{ Domain } & \multicolumn{2}{|c|}{ Threshold $(d)$ Value } & \multicolumn{2}{|c|}{ Expert Agreement (\%) } & \multicolumn{2}{|c|}{$\begin{array}{c}\text { Average of Fuzzy Score } \\
\left(A_{\max }\right)\end{array}$} & \multicolumn{2}{|c|}{ Result } & \multicolumn{2}{|c|}{$\begin{array}{l}\text { Ranking by the } \\
\text { Fuzzy Score }\end{array}$} \\
\hline & (U) & (A) & (U) & (A) & (U) & (A) & (U) & (A) & (U) & (A) \\
\hline Smart Economy & 0.142 & 0.139 & $76 \%$ & $89 \%$ & 0.725 & 0.731 & Accepted & Accepted & 2 & 2 \\
\hline Smart Living & 0.132 & 0.171 & $75 \%$ & $91 \%$ & 0.719 & 0.700 & Accepted & Accepted & 4 & 4 \\
\hline Smart Environment & 0.189 & 0.212 & $57 \%$ & $55 \%$ & 0.654 & 0.639 & Rejected & Rejected & 7 & 7 \\
\hline Smart People & 0.123 & 0.128 & $80 \%$ & $83 \%$ & 0.745 & 0.743 & Accepted & Accepted & 1 & 1 \\
\hline Smart Government & 0.188 & 0.184 & $92 \%$ & $91 \%$ & 0.704 & 0.698 & Accepted & Accepted & 5 & 5 \\
\hline Smart Mobility & 0.164 & 0.245 & $83 \%$ & $56 \%$ & 0.724 & 0.654 & Accepted & Rejected & 3 & 6 \\
\hline $\begin{array}{l}\text { Smart Digital } \\
\text { Infrastructure }\end{array}$ & 0.204 & 0.150 & $72 \%$ & $74 \%$ & 0.670 & 0.725 & Rejected & Rejected & 6 & 3 \\
\hline
\end{tabular}

Note: U stands for Understanding, A stands for Acceptance. Three conditions to accept an item: threshold value $(d) \leq 0.2$, percentage of experts' consensus $\geq 75 \%$, and average fuzzy score $\left(A_{\max }\right) \geq \alpha-$ cut value $=0.5$.

To accept the criteria of the Fuzzy Delphi analysis, the results must meet three conditions: (a) threshold value, $d \leq 0.2$, (b) expert agreement percentage $\geq 75 \%$, and (c) average fuzzy score $\left(A_{\max }\right) \geq \alpha-$ cut value $=0.5$. Overall, all the domains fulfilled the third criteria, with fuzzy scores equal to or exceeding 0.5 . Meanwhile, the threshold value and expert agreement showed mixed results.

To provide more detail on the item results, as shown in Table 11, the smart economy and living had a 100\% acceptance rate for the objective of Acceptance, hinting that these two domains can be implemented directly at ground level with little modification. On the other hand, the smart environment scored the lowest acceptance rates, $22.22 \%$ for the Understanding objective and $33.33 \%$ for the Acceptance objective. This result indicates that the smart environment domain has experienced great public dissensus and more refinement is needed before its implementation to avoid later failures.

Table 11. Results of Fuzzy Delphi analysis by objectives.

\begin{tabular}{|c|c|c|c|c|c|c|c|}
\hline Objective & Domain & Item & Accepted Item & $\%$ of Acceptance & Rejected Item & $\%$ of Rejection & Fuzzy Score Interval \\
\hline \multirow[t]{7}{*}{ Understanding } & Economy & 7 & 5 & 71.43 & 2 & 28.57 & $0.775-0.655=0.120$ \\
\hline & Living & 5 & 4 & 75.00 & 1 & 25.00 & $0.775-0.620=0.155$ \\
\hline & Environment & 9 & 2 & 22.22 & 7 & 77.78 & $0.745-0.572=0.173$ \\
\hline & People & 6 & 4 & 66.67 & 2 & 33.33 & $0.765-0.715=0.050$ \\
\hline & Government & 4 & 3 & 75.00 & 1 & 25.00 & $0.725-0.693=0.032$ \\
\hline & Mobility & 8 & 6 & 75.00 & 2 & 25.00 & $0.755-0.685=0.070$ \\
\hline & $\begin{array}{c}\text { Digital } \\
\text { Infrastructure }\end{array}$ & 6 & 3 & 50.00 & 3 & 50.00 & $0.735-0.523=0.212$ \\
\hline \multirow[t]{7}{*}{ Acceptance } & Economy & 7 & 7 & 100.00 & 0 & 0.00 & $0.770-0.710=0.060$ \\
\hline & Living & 5 & 5 & 100.00 & 0 & 0.00 & $0.725-0.670=0.055$ \\
\hline & Environment & 9 & 3 & 33.33 & 6 & 66.67 & $0.720-0.557=0.163$ \\
\hline & People & 6 & 4 & 66.67 & 2 & 33.33 & $0.770-0.720=0.050$ \\
\hline & Government & 4 & 3 & 75.00 & 1 & 25.00 & $0.715-0.680=0.035$ \\
\hline & Mobility & 8 & 3 & 37.50 & 5 & 62.50 & $0.700-0.563=0.137$ \\
\hline & $\begin{array}{c}\text { Digital } \\
\text { Infrastructure }\end{array}$ & 6 & 4 & 66.67 & 2 & 33.33 & $0.760-0.655=0.105$ \\
\hline Total & & 90 & 54 & 61.36 & 34 & 38.64 & \\
\hline
\end{tabular}

Note: Refer Appendix B for detailed calculations.

In general, the results of the analysis on the smart economy, living, people, and governance domains met all three conditions of the Fuzzy Delphi method in terms of Understanding and Acceptance. However, some item details must be addressed (refer to Appendix B).

First, for the Understanding objective of the smart economy, the two rejected items were items 3 (high value-added industry investment, with threshold value $d=0.21$, and expert agreement at only 33\%) and 7 (assistance to business operations, with 73\% expert agreement). For the Acceptance objective of the smart economy, all the items were ac- 
cepted. For the high value-added industry investment, the respondents did not arrive at a consensus. Some thought that the authorities should focus on the manufacturing sector, especially in suburban and rural areas, instead of prioritizing high value-added industry, which would accelerate the existing urbanization issues in metropolitan Malaysia, such as in Kuala Lumpur and the Klang Valley area.

Second, under smart living, the only problematic Understanding item was item 1 (crime reduction). Respondents were less able to comprehend why Malaysia was stated as having a high, instead of moderate, crime rate, since most of them lived in peaceful environments. Meanwhile, they were inclined to accept that the MSCF would be able to reduce the crime rate effectively through ICT applications, such as the installation of CCTV in public areas.

Third, for the understanding and acceptance of smart people, all four rejected items were due to the $70 \%$ to $73 \%$ expert agreement. For item 3, the acceptance of the education policy for human capital development, respondents were not fully confident that the restructuring of education at the tertiary level would produce innovative graduates. One respondent commented that the current graduate market indicated that graduates were able to perform at routine levels while lacking innovative thinking and solution-creation skills.

Fourth, for the understanding and acceptance of smart governance, item 3-intergovernmental data sharing - was the only item rejected as the threshold value $d=0.224$ and 0.202. Respondent feedback suggested that they did not understand how intergovernmental data could be shared in practice, as some were still experiencing issues such as the separate performance of departments, the redundancy of providing data to particular departments, and the inability to receive valid and complete data through a single department enquiry. For example, the Department of Statistics does not provide open demographic data by city or district level so one needs to go to the particular local authorities.

The major focus of this study should be the smart environment and digital infrastructure domains because both were rejected in terms of the understanding and acceptance objectives. In general, for the environment, its threshold $(d)$ construct for Acceptance $(0.212)$ was more than 0.2 while both values of expert agreement (57\% for Understanding and $55 \%$ for Acceptance) were less than $75 \%$. For digital infrastructure, its threshold (d) construct for Understanding (0.204) was also more than 0.2 while both values of expert agreement ( $72 \%$ for Understanding and $74 \%$ for Acceptance) were also less than $75 \%$. These negative results show that the public remain less likely to understand and accept the components planned in these two domains, smart environment, and digital infrastructure.

In detail, for the smart environment, the three lowest-ranked Understanding items related to items 1 (park and green area management), 8 (non-revenue water management and reporting), and 9 (low-carbon city and carbon emissions). Meanwhile, the three lowest-ranked Acceptance items related to items 7 (readiness towards disaster-resilient cities), 4 (air quality monitoring) and 2 (waste segregation and recycling). From the overall perspective, the environment-related issues worrying the public are broad in scope and a cause for grave alarm. The smart environment domain facings major public understanding and acceptance issues and the authorities should prioritize improvements in this domain.

For the smart digital infrastructure, two items of interest in terms of Understanding are items 6 (cybersecurity) and 5 (personal data protection); for Acceptance, they are items 1 (roles of service providers) and 2 (internet speed). It seems that respondents lacked confidence in the authority's online system security and personal data protection, and felt they were vulnerable to cyber-attacks and personal data leaks. Attention should also be given to the respondents who did not fully accept that private service providers were solely responsible and thought that the government was too. Another important issue involved rural areas with low internet speeds of $4 \mathrm{G}$ and below.

For the smart mobility, the result was accepted for Understanding but rejected for Acceptance. The acceptance of respondents was rejected since the threshold $(d)$ conduct 
was 0.245 , which is over the 0.2 required; furthermore, the expert agreement of $56 \%$ was much less than the $75 \%$ required.

Clearly, the rejection phenomenon identified for the Acceptance objective needs attention. A low level of expert agreement was observed for items 6 (electric vehicle), 1 (smart traffic management), 8 (public transport application), and 5 (smart parking infrastructure). These results showed that the respondents were worried about the traffic planning presented in the MSCF and were unconvinced by the solutions related to the issues stated above.

\section{Discussion}

\subsection{Voicing Dissensus Opinions for Building a More Inclusive Smart City Blueprint}

The findings indicate divergent expert perceptions. The different job roles and employment sectors of the respondents could be expected to produce diverse results. Figure 4 summarizes the occurrence of three conditions.

\section{Understanding and Acceptance of Smart City Domains}

Confirmed

(Understanding and Acceptance)
Rejected

(Understanding and Acceptance)
Rejected

(Acceptance)

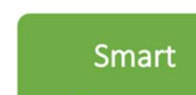

Economy
Smart

Living

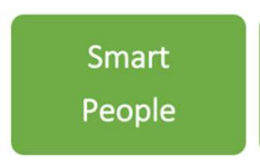

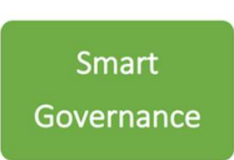

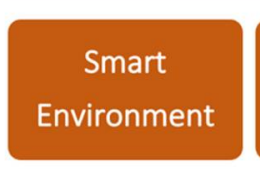

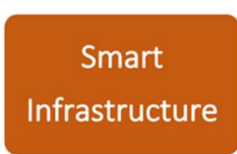

Smart

Mobility

Figure 4. Dissensus opinions on the understanding and acceptance of smart city domains.

The dissensus in the results is a finding that leaders and policymakers should be aware of. They should accept this reality and include those opinions that do not always favor the majority. For example, people were dissatisfied with the smart environment domains; for example, they did not comprehend the ineffectiveness of the authorities' park and green area management and preservation, nor did they accept that the authorities had done enough pertaining to this matter. Evidence from $[2,20]$ showed that the smart environment covers a wide range of natural resources preservation and the resilience of human actions to the impact of climate change; thus, it is crucial to contemplate the divergent opinions from the respondents.

For smart digital infrastructure, respondents did not recognize that their personal data are protected by the Malaysia Personal Data Protect Act 2010; they felt unsafe from cyber-attacks and were also unconvinced that the authorities would reduce cyber threats and have a positive impact by protecting online users.

For smart mobility, although most understood that this domain is important, they showed disagreement in accepting the implemented initiatives. For example, they did not express confidence in the promotion of autonomous, and electric or green vehicles, smart traffic light functioning, and public transport applications. This finding is interesting from a global perspective as these measures are working elsewhere in other countries, meaning they were understood by the respondents. However, it is clear that the authorities should improve these matters to bring about greater local acceptance and avoid wasted investment. The following subsections provide various ideas for reconsidering the implementation of smart city domains in MSCF.

In the broader topic of smart city's understanding and acceptance, the above result reflected a developing country's context and dynamic in practice [1,14]. The administrators should be responsive and improve the smart city domains and strategies from time to 
time. As for the specific scientific field, the smart environment needs more attention as climate change is real $[2,20,87]$ and applying smart digital infrastructure with higher security $[21,22,37]$ to counter this global issue is urgently needed to be addressed.

\subsection{Rethinking the Viability of Smart City Domains and Strategies}

A smart economy tends to possess high value-added industries, so it is proposed that high value-added industrial investment promotion initiatives be reconsidered geographically as the distribution of secondary industry is unbalanced and currently heavily favors the Peninsula and urban areas [119]. Sabah and Sarawak are still heavily dependent on primary products (i.e., timber, oil, and LNG). Targeting the relocation of manufacturing sectors to less-developed areas, which would create new urban growth centers or smart cities, needs far more attention, rather than targeting high-value investment in the already mature urban and metropolitan areas. Furthermore, wages in less-developed areas need to be improved since continuing to invest in high-value industries in urban areas will further exacerbate the urbanization issues. Malaysia could learn from India in promoting balanced and sustainable economic growth and ensuring all economic activities work well at the local level (refer to [20]). Furthermore, Malaysia could also learn from Hong Kong in placing greater focus on sharing economic activities among regions and in the re-industrialization of the necessary supporting primary and secondary sectors (refer to [8]).

Another point to consider is the potential of e-commerce. Online transaction expansion initiatives that are gaining a place in the hearts of consumers can be created in line with the increasingly busy lifestyle of urban citizens. A study of online purchasing practices in Malaysia by [120] found that buying online was chosen because it is a convenient and easy way to shop for necessities while avoiding long queues at the counter. Online shopping is a trend in modern society since internet usage has increased in the last decade. It has accelerated under the stay-at-home new normality caused by the COVID-19 pandemic threat. Thus, considering online shopping initiatives as part of the smart economy initiative should enable improvements in the economic status of urban residents, either as traders or customers, which would facilitate the lives of both parties [25].

For smart living, the experts rejected the understanding that the crime rate in Malaysia remains high compared to other countries. The respondents thought that the crime rate was under control level. This opinion matches the findings of [121], whose local studies in Kuala Lumpur showed that city residents are comfortable with the crime situation. Additionally, Ref. [121] found that the perception that the crime rate was high in Malaysia actually did exist in the foreign discourse. Thus, the authorities could consider all such perspectives, turning their focus to the means of adaptation to the fear of crime, the omnipresence of police in public spaces, and assistance to prevent criminal acts in community areas $[47,121]$.

Furthermore, in terms of smart living, voluntary and more active community involvement initiatives related to the safety, educational, and health aspects of the local community can be added to reduce the extent of the dependence on government resources. According to [122], community involvement ensures that the needs and aspirations of the community are not neglected; the result is that community members will be educated and subsequently empowered. This shows that the role of the community can resolve local issues more effectively.

In terms of smart people, referring to skilled and talented human capital, the government must rethink tertiary education and determine how to actively produce digitally talented innovative graduates to suit the value-added industry in the Industry 4.0 era. More structured and holistic learning opportunities within the areas of IoT devices development, telecommunications, middleware, big data analytics, and artificial intelligence are needed. This is because engineering students currently focus mainly on hardware and connectivity aspects while computer science students learn middleware and big data analytics separately [104]. To adopt Industry 4.0 technologies in Malaysian smart city society, a radical paradigm shift in educating graduates so they transform into talented human capital should be the priority, a notion that was reaffirmed by the Prime Minis- 
ter [67]. Thus, the 2013 national education policy is somewhat outdated, so rethinking how to enhance it through the Industry 4.0 perspective is crucial. Questions such as how to nurture young people so they master the fundamental Industry 4.0 technologies in stages, from primary, secondary, and tertiary education up to life-long learning for the elderly community members, should become the central aim in formulating a new national education policy.

Next, moral and ethical development, as mentioned in the MSCF, is considered a good move for developing countries like Malaysia, as many Western developed countries have resolved this moral element (refer to [2]). As mentioned in the literature, Ungku Aziz's 1980s ideas are still considered fundamental and remain relevant enough to be adopted in the current smart city development in Malaysia. Although the values of education related to moral development were stated in the National Education Blueprint 2013, the latest education plan could be enhanced based on the five principles of Maqasid Al-Syariah, namely caring for religion, caring for life, caring for intellect, caring for one's offspring, and caring for property. Maqasid Al-Syariah refers to the noble purpose of Islamic law, which is based on the principle of Maslahat and which mankind could universally obtain through the text or authority of Islamic law [123]. This universal concept is seen by all as practicable.

Another aspect to enhance in terms of smart people in Malaysia is the level of civic participation in local authority decision-making and programs [73]. Participation in decisionmaking differs from community empowerment: the former involves the level of citizen power and can influence agenda setting, while the latter refers to the tokenism level of service delivery stages [61]. Furthermore, in the former, people are active in decision-making and co-creating with the authorities, whereas, in the latter, people tend to be in a weaker, beneficiary, or reactive position when they are deemed 'empowered' by the authorities. Contemplating the lower level of participation in decision-making in Malaysia, the authors argue that the implementation of the MSCF could enhance the extent of this form of participation. Although it may face dissensus of opinion, in the long term, this move will help in building more democratic spaces and independent citizenship for Malaysian nation-building [124].

On the governance issue, excessive bureaucracy, delays in approving applications and licenses, as well as a lack of information on new policies and regulations are among the main problems plaguing the government's delivery system [81,82]. Inter-governmental data sharing is another challenge due to the separate departmental practices in Malaysia. To address this, Hong Kong's initiatives can be adopted, such as building a new big data analytics platform; adopting public cloud services, which would enable real-time data transmission and sharing among government departments; and enhancing security features so that government departments can deliver efficient and agile e-services [8]. Future smart city governance should make effective use of their data assets to secure outcomes that are appropriate to citizens' needs. Investment by agencies in system-wide data capture, integration, and analytics capabilities [75] is a crucial aspect to develop.

Apart from data sharing, smart governance ultimately aims to produce public values for citizens, such as from the perspective of asset management and financial and economic sustainability [93]. To realize such public values, e-democracy must be upheld through active e-voting and e-decision making [71], which is a major topic for Malaysian smart development advocates to deliberate. According to the Democracy Index 2020, out of 167 countries, Malaysia (ranked 39) and India (ranked 53) fell into the category of flawed democracies. Meanwhile, Hong Kong ranked 87 due to its hybrid regime of flawed democracy and authoritarian control [125]. In terms of the purpose of building independent citizens [2] within the conception that smart cities are democratic ecologies [126], Malaysia and similar places must actually strive further to achieve higher transparency and open governance. As suggested by [127], 'good enough governance' for smart city societies in Malaysia should consider the cultural context of the Muslim majority, prioritize governance 
content that allows more scope for political participation and free speech, and cultivate the imagination and unselfishness of children.

Furthermore, it was found that the understanding and acceptance of initiatives in the smart environment is the most critical among all the domains. In this regard, announcements on smart environment initiatives must be intensified and expanded to ensure the sustainability of the existing environment. Most importantly, the authors' view is that environmental accountability initiatives must be added to this component to enable each party to understand the concept and play their respective roles in caring for the environment. In the case of maintaining a clean environment, Ref. [57] found that all stakeholders should take responsibility, not solely the authorities. Efforts to maintain and preserve the environmental space relate to the question of community awareness and attitude, which, if sufficiently high, would ensure that the environment is always clean, healthy, and sustainable.

In terms of preserving parks and green spaces in urban areas, Malaysia's development control guidelines set a minimum of $10 \%$ green and open space reservation, which is considered relatively low. In comparison, the city of Wuhan, China, has launched its Wuhan Low-Carbon Urban Development Plan 2013, which reserves 28\% for green areas in the city [48]. Therefore, a rethink is suggested that would impose a greater green space allocation in new development plans and, together with agencies such as PLANMalaysia, the MSCF could incorporate this higher green space allocation as one of its smart environment initiatives.

In terms of smart mobility and, in particular, electrical vehicles (EVs) in Malaysia, Putrajaya city bought 150 electric buses (each costing RM 1.5 million). They operate in Putrajaya and the vicinity, the aim being to cut carbon emissions, noise pollution, and traffic congestion while improving public transport and parking systems [128]. The operation of the electric buses is calibrated by battery capacity and charging facilities and has been found to outperform conventional bus operations [129]. However, cases of the inefficiency of public transport management were identified, whereby the electric buses were found abandoned at the Depoh Putrajaya. Bus breakdowns are frequent due to lack of maintenance, unreliable and delayed bus arrival times, and reductions in bus routes [130]. Thus, although electric cars are efficient in costs and energy saving with long-term usage [84], the adoption of an EV ecosystem is required, involving features such as efficient management and the availability of efficient power charging stations.

As for privately-owned electric cars, it has been found that the understanding and acceptance of the community is still low. The respondents in this study felt the costs involved in owning and maintaining a private electric vehicle were higher than those of a typical vehicle. It is true that research has shown that the cost of electric vehicle ownership in Malaysia is not yet as competitive as typical internal combustion vehicles [131]. This shows the market and society acceptance of electric cars remains still low. Those involved in the MSCF should rethink the issues of EVs, along with the latest National Automotive Policy 2020, in promoting affordable new technologies. For example, incentives and funding are available under the National Automotive Policy 2020 to develop the technology and engineering required for NxGV (next-generation vehicles), autonomous vehicles, MaaS (mobility-as-a-service), and Industry 4.0 [132]. Thus, MSCF initiatives such as promoting collaboration with the private sector in developing affordable EVs could be implemented.

Last but not least, for the smart digital infrastructure, in terms of the cybersecurity and personal data protection issues, it seems that the MSCF did not provide clear direction on how to strengthen the necessary cybersecurity and personal data protection. The ranking of Malaysia as eighth out of 194 countries in the Global Cybersecurity Index 2021 [133] seems to contradict the results of this study's finding. Recently reported cyber intrusion cases [103] were over the targeted 9000 to 10,000 per year [9], and the assessment of the National IoT Strategic Roadmap was also ambiguous [104]. All the supporting agencies, such as Cybersecurity Malaysia, the Department of Personal Data Protection, and the Malaysia Administrative Modernization and Management Planning Unit must work 
more closely together and actively provide improvements or amendments to the policies, especially more strict enforcement of the Malaysian Personal Data Protection Act 2010.

As for the issues of low internet speed and digital infrastructure coverage in lessdeveloped states and rural areas, more MSCF initiatives could be planned in conjunction with the latest National Digital Infrastructure Plan (JENDELA), the Malaysian Industry 4.0 Policy, and the Malaysia Digital Economy Blueprint (MyDigital). For instance, the current wireless broadband coverage in Malaysia is $96.7 \%$ for $2 \mathrm{G}, 95.3 \%$ for $3 \mathrm{G}$, and $91.8 \%$ for $4 \mathrm{G}$ coverage in populated areas, with $25 \mathrm{Mbps}$ speed [134]. Therefore, MSCF initiatives could plan to achieve $100 \% 4 \mathrm{G}$ coverage in populated areas and a speed of $100 \mathrm{Mbps}$ by adopting $5 \mathrm{G}$.

\section{Conclusions}

First, Malaysia's experience in smart city development dates back to 1996 Multimedia Super Corridor Malaysia initiative and the later efforts in developing research universities and integrating them with the city they are located $[135,136]$ — through knowledge-based urban development principles to make space and place for smart urban communities [137]. Today, with its new smart city framework, Malaysia aims to transform its cities and societies into smarter ones. This paper aims to generate insights into how this framework is perceived with professional practitioners. In order to do so, this study conducted an empirical investigation concerning the seven smart city domains planned as part of a top-down national policy of the Malaysian Smart City Framework (MSCF). The findings disclosed that smart environment and digital infrastructure require the most attention, followed by smart mobility, governance, living, economy, and people.

Second, this study has contributed to the smart city discourse and literature particularly by examining the levels of understanding and acceptance from the multi-perspectives of practitioners from various sectors. The study is unique as it is one of the first in capturing professional practitioners' voices and perspectives on a national level smart city policy that impacts a large portion of the population. This finding is an important insight added to the literature investigating, in detail, smart city domains in practice. The divergent and dissensus opinions from the ground are valuable references for leaders and policymakers to consider in building a more inclusive and smarter city blueprint. Furthermore, applying the Fuzzy Delphi method in smart city studies is rather new. It has great potential to be explored and expanded into urban studies and planning disciplines as this method is popular in education, business, and management studies [138].

Last, the limitations of this study are the selection of purposive sampling for the Fuzzy Delphi analysis and the formulation of questionnaire items from the broader scopes of the smart city domains. Thus, based on the smart city domains and after designing two objectives of understanding and acceptance, future studies could explore other qualitative or quantitative methods to justify the results in this study. Other studies that evaluate the implementation of the smart city domain objectives could be conducted, such as using structural equation modelling to assess the implementation of smart city strategies in Greece [139] and acceptance of smart meters in Malaysia [37]. Moreover, future studies could be expanded to capture the voices and perspectives of the general public on national and local smart city strategy and initiatives. This will be the focus of our prospective study.

Author Contributions: Conceptualization and methodology, writing-original draft preparation, software, formal analysis, investigation, and data curation, S.B.L.; supervision, validation, resources, funding acquisition, project administration, review and editing, J.A.M., M.F.Y.M.Y. and T.Y. All authors have read and agreed to the published version of the manuscript.

Funding: The study received funding support from the Malaysian Ministry of Higher Education (grant number FRGS/1/2019/SS06/UKM/02/2). The funder was not involved in the planning, execution, write-up, or other contents of this article.

Institutional Review Board Statement: Not applicable.

Informed Consent Statement: Informed consent was obtained from all participants involved in the study. 
Data Availability Statement: Data are contained within the article and appendixes.

Acknowledgments: The authors wish to thank study participants, managing editor and three anonymous reviewers for their invaluable comments and constructive critiques.

Conflicts of Interest: The authors declare no conflict of interest and have no financial or proprietary interests in any material presented/discussed in this article.

Appendix A. Survey Items

Table A1. Domain 1: Smart Economy.

\begin{tabular}{|c|c|c|}
\hline Item & Understanding & Acceptance \\
\hline $\begin{array}{l}\text { Intensify technology application and } \\
\text { digitalization in core business functions }\end{array}$ & $\begin{array}{l}\text { I am aware that the use of technology in the } \\
\text { services sector needs to be expanded and } \\
\text { intensified in order to be able to compete with } \\
\text { the use of technology in the manufacturing } \\
\text { sector. }\end{array}$ & $\begin{array}{l}\text { I am sure the application of technology and } \\
\text { digitization in core business functions can be } \\
\text { implemented quickly. }\end{array}$ \\
\hline Enhance the usage of e-payment & $\begin{array}{l}\text { I understand that the widespread use of debit } \\
\text { and credit cards catalyzes e-payment. }\end{array}$ & $\begin{array}{l}\text { I am ready to use e-payment in my daily } \\
\text { affairs. }\end{array}$ \\
\hline $\begin{array}{l}\text { Attract investment in high value-added } \\
\text { industries }\end{array}$ & $\begin{array}{l}\text { I understand that investment promotion } \\
\text { activities have been restructured to target high } \\
\text { value-added industry investors. }\end{array}$ & $\begin{array}{l}\text { I am confident that the attractiveness of high } \\
\text { value-added investments can be increased } \\
\text { from time to time. }\end{array}$ \\
\hline $\begin{array}{l}\text { Create a workforce to match jobs in high } \\
\text { value-added industries }\end{array}$ & $\begin{array}{l}\text { I am aware that computer science skills and } \\
\text { critical thinking need to be widely } \\
\text { disseminated as the high value-added industry } \\
\text { sector requires creative and innovative } \\
\text { employees. }\end{array}$ & $\begin{array}{l}\text { I am sure the matching of high-income work } \\
\text { with high value-added industries can be more } \\
\text { efficient. }\end{array}$ \\
\hline $\begin{array}{l}\text { Provide technology labs and collaborative } \\
\text { platforms }\end{array}$ & $\begin{array}{l}\text { I understand that the strengthening and } \\
\text { establishment of technology laboratories can } \\
\text { help entrepreneurs to become more efficient in } \\
\text { penetrating a wider market. }\end{array}$ & $\begin{array}{l}\text { I am confident that the establishment of } \\
\text { technology laboratories and collaborative } \\
\text { platforms can enhance knowledge exchange in } \\
\text { various fields. }\end{array}$ \\
\hline Establish incubators and accelerators & $\begin{array}{l}\text { I understand that incubators and drivers need } \\
\text { to work more closely to meet market needs. }\end{array}$ & $\begin{array}{l}\text { I am sure the creation of incubators and } \\
\text { drivers can help realize new ideas to produce } \\
\text { more competitive businesses that impact the } \\
\text { local community and society. }\end{array}$ \\
\hline $\begin{array}{l}\text { Leverage existing government assistance and } \\
\text { funding }\end{array}$ & $\begin{array}{l}\text { I understand that the assistance provided by } \\
\text { various government agencies should be used } \\
\text { optimally to improve business operations. }\end{array}$ & $\begin{array}{l}\text { I am confident that the optimal use of facilities } \\
\text { provided by the Government can help } \\
\text { improve business operations. }\end{array}$ \\
\hline
\end{tabular}

Table A2. Domain 2: Smart Living.

\begin{tabular}{lll}
\hline \multicolumn{1}{c}{ Item } & \multicolumn{1}{c}{ Understanding } & \multicolumn{1}{c}{ Acceptance } \\
\hline $\begin{array}{l}\text { Enhance safety and security through } \\
\text { perspectives of crime }\end{array}$ & $\begin{array}{l}\text { I understand the crime rate in Malaysia is } \\
\text { still high compared to other countries. }\end{array}$ & $\begin{array}{l}\text { I am sure the installation of analytical } \\
\text { proactive surveillance, such as CCTV, can } \\
\text { reduce the crime rate in Malaysia. } \\
\text { I believe that the adoption of smart home } \\
\text { applications, such as facial recognition } \\
\text { Promote quality housing }\end{array}$ \\
$\begin{array}{ll}\text { I understand the promotion of the smart } \\
\text { home can improve the quality of life. } \\
\text { better quality housing. }\end{array}$ & $\begin{array}{l}\text { I understand that an emergency call } \\
\text { center can help in cases of emergency, } \\
\text { such as fire. }\end{array}$ & $\begin{array}{l}\text { I believe that the adoption of an } \\
\text { emergency call center with a real-time } \\
\text { mobile rescue application is crucial when } \\
\text { an emergency occurs. }\end{array}$ \\
Enhance the quality of healthcare services \\
$\begin{array}{l}\text { I believe good healthcare can improve the } \\
\text { quality of life. } \\
\text { I believe that urban farming activities can } \\
\text { enhance the relationship between }\end{array}$ & $\begin{array}{l}\text { I believe that the Smart City Framework } \\
\text { is able to facilitate public health services. } \\
\text { I am confident that through urban } \\
\text { farming, a community can work together } \\
\text { more closely and appreciate each other. }\end{array}$ \\
\hline
\end{tabular}


Table A3. Domain 3: Smart Environment.

\begin{tabular}{c} 
Item \\
\hline Preserve green areas and enhance the \\
management of trees in public parks
\end{tabular}
management of trees in public parks

Strengthen integrated and sustainable solid waste management

Strengthen the solid waste laws and policies

Improve the air quality and its monitoring system

Improve the water quality and its monitoring system

Increase energy efficiency and promote renewable energy sources

Enhance disaster risk management by adopting advanced technology applications

Enhance Non- Revenue Water Management

Encourage the development of the low-carbon city concept to be adopted at the local level

Understanding

I understand that local authorities have improved the management efficiency of public parks, such as adapting the use of smart management systems to preserve green areas (i.e., the use of RFID technology to inventory existing trees). I am aware that waste segregation at source and the recycling of waste are the best solid waste management methods to maintain environmental sustainability. I am of the view that the government has provided adequate laws and policies to improve solid waste management in the country.

I am aware of the importance of using public transport as an initiative to reduce carbon emissions that can affect the environmental air quality.

I understand that the government has, over time, improved the efficiency of the water monitoring system technology.

I find that efforts are being made by the government and the private sector to increase the use of renewable energy in the community.

I understand that the government has implemented disaster risk management through the use of the latest technology, such as warning delivery systems, to facilitate the delivery of information to the public.

I am of the view that public understanding of the importance of non-revenue water management in water resources management has increased. I understand that the implementation of initiatives to reduce carbon emissions from buildings and vehicles has been implemented in tandem with the urbanization process.

\section{Acceptance}

I gain positive effects from the use of well-managed public parks and green areas by local authorities, such as increased social interaction, peace of mind, and stress reduction.

I always practice waste segregation at source and the recycling of waste items at home and work.

I am confident that the laws and policies formulated by the government can improve the sustainability of the country's solid waste management.

I strive to increase my use of modes of public transportation in day-to-day affairs to help reduce carbon emissions.

I am confident that the improvement of water monitoring system technology in urban areas by the government will provide a high-quality, clean water source for residents.

I have applied the use of energy-efficient appliances, such as LED lighting, at home and at work to reduce the use of electricity generated from fossil fuels.

I participate in disaster management awareness programs organized at the community level so that I can be better prepared in the event of a disaster.

I immediately make an online report to the agency or responsible party when faced with incidents such as a burst pipe.

I believe the development of low-carbon cities by private developers is a positive step towards reducing the carbon footprint of urban areas.

Table A4. Domain 4: Smart People.

\begin{tabular}{lll}
\hline \multicolumn{1}{c}{ Item } & \multicolumn{1}{c}{ Understanding } & \multicolumn{1}{c}{ Acceptance } \\
\hline Improve moral education in schools & $\begin{array}{l}\text { I agree that the element of moral } \\
\text { education among the younger generation } \\
\text { is important as it is an initial step in the } \\
\text { formation of an ethical society. }\end{array}$ & $\begin{array}{l}\text { I welcome the government's intention to } \\
\text { improve moral education and prioritize it } \\
\text { in the early stages of schooling. }\end{array}$ \\
$\begin{array}{l}\text { Enhance public awareness in practicing } \\
\text { good morals and civics }\end{array}$ & $\begin{array}{l}\text { I understand and realize that the concept } \\
\text { of a moral and ethical society is an } \\
\text { important element in building a smart } \\
\text { city culture. }\end{array}$ & $\begin{array}{l}\text { I agree that the building of a smart city } \\
\text { community culture can be achieved } \\
\text { through civic awareness programs on } \\
\text { public facilities, the environment, and the } \\
\text { importance of community living. }\end{array}$ \\
\hline
\end{tabular}


Table A4. Cont.

\begin{tabular}{|c|c|c|}
\hline Item & Understanding & Acceptance \\
\hline $\begin{array}{l}\text { Increase the volume of skilled and } \\
\text { talented human capital at every level }\end{array}$ & $\begin{array}{l}\text { I think that the formation of an educated } \\
\text { and highly skilled generation is an } \\
\text { important aspect of building a } \\
\text { knowledgeable society as part of the } \\
\text { construction of smart cities. }\end{array}$ & $\begin{array}{l}\text { I am confident that the restructuring of } \\
\text { the education policy at every level in the } \\
\text { fields of research, science and technology } \\
\text { will produce a generation of } \\
\text { highly-educated, skilled and innovative } \\
\text { people. }\end{array}$ \\
\hline $\begin{array}{l}\text { Enhance public participation and } \\
\text { community empowerment initiatives }\end{array}$ & $\begin{array}{l}\text { I realize that community participation, } \\
\text { community engagement, and community } \\
\text { empowerment are highly important in } \\
\text { every policy formation of a country and } \\
\text { lead to the well-being of the people. }\end{array}$ & $\begin{array}{l}\text { I agree the community needs to be } \\
\text { directly involved in the making of every } \\
\text { government policy and initiative through } \\
\text { a simple and fast digital platform. }\end{array}$ \\
\hline $\begin{array}{l}\text { Improve gender sensitization and the } \\
\text { inclusivity of vulnerable groups }\end{array}$ & $\begin{array}{l}\text { I am aware that the interests and needs of } \\
\text { women and people with disabilities } \\
\text { (OKU) must be taken into account in } \\
\text { every aspect of urban development } \\
\text { planning. }\end{array}$ & $\begin{array}{l}\text { I support the idea that facilities are } \\
\text { provided in every urban development, } \\
\text { which through a digital medium, take } \\
\text { into account the needs and safety of all } \\
\text { groups, especially women and people } \\
\text { with disabilities (OKU). }\end{array}$ \\
\hline $\begin{array}{l}\text { Increase public willingness to adapt to } \\
\text { emerging technologies }\end{array}$ & $\begin{array}{l}\text { I understand that the concept of the } \\
\text { smart city formation will be formed from } \\
\text { a skilled and efficient society and with } \\
\text { the use of IT. }\end{array}$ & $\begin{array}{l}\text { I agree that it is time for digital skills to } \\
\text { be learned earlier in childhood and } \\
\text { subsequently introduced into continuous } \\
\text { learning in the community through } \\
\text { digital billboards placed in public spaces. }\end{array}$ \\
\hline
\end{tabular}

Table A5. Domain 5: Smart Government.

\begin{tabular}{|c|c|c|}
\hline Item & Understanding & Acceptance \\
\hline & I understand that through the Smart City & I believe that through the Smart City \\
\hline $\begin{array}{l}\text { Increase the scope of e-government } \\
\text { services }\end{array}$ & $\begin{array}{l}\text { Framework, the government can widen } \\
\text { the scope of government services to the } \\
\text { community. }\end{array}$ & $\begin{array}{l}\text { Framework, a wider range of } \\
\text { government services will be available to } \\
\text { the community. }\end{array}$ \\
\hline $\begin{array}{l}\text { Increase the quality of e-government } \\
\text { services }\end{array}$ & $\begin{array}{l}\text { I understand that the use of the Smart } \\
\text { City Framework can improve the quality } \\
\text { of e-government services. }\end{array}$ & $\begin{array}{l}\text { I believe the Smart City Framework can } \\
\text { improve e-government services to the } \\
\text { community. }\end{array}$ \\
\hline $\begin{array}{l}\text { Elevate the use of data sharing platforms } \\
\text { across government agencies }\end{array}$ & $\begin{array}{l}\text { I am confident that if inter-governmental } \\
\text { data sharing works well, there will be } \\
\text { fewer community complaints and } \\
\text { better-quality government/private } \\
\text { services. }\end{array}$ & $\begin{array}{l}\text { Through inter-governmental data } \\
\text { sharing, I have received valid and } \\
\text { accurate data/information from } \\
\text { government/private organizations. }\end{array}$ \\
\hline $\begin{array}{l}\text { Promote the use of information } \\
\text { disclosure and open data on behalf of the } \\
\text { government }\end{array}$ & $\begin{array}{l}\text { I understand that the dissemination of } \\
\text { open data and authentic information can } \\
\text { expedite the transparency of } \\
\text { governmental services. }\end{array}$ & $\begin{array}{l}\text { I agree that the accessibility of open data } \\
\text { and information dissemination would } \\
\text { benefit all. }\end{array}$ \\
\hline
\end{tabular}

Table A6. Domain 6: Smart Mobility.

\begin{tabular}{lll}
\hline \multicolumn{1}{c}{ Item } & \multicolumn{1}{c}{ Understanding } & \multicolumn{1}{c}{ Acceptance } \\
\hline & $\begin{array}{l}\text { I understand the importance of smart } \\
\text { transportation management, such as the }\end{array}$ & $\begin{array}{l}\text { I am satisfied with the way smart } \\
\text { transportation management functions, } \\
\text { Establish intelligent transport }\end{array}$ \\
management & $\begin{array}{l}\text { use smart traffic lights, the use of } \\
\text { sensors for traffic management, and } \\
\text { pollution tracking. }\end{array}$ & $\begin{array}{l}\text { suse of smart traffic lights, } \\
\text { the use of sensors for traffic management, } \\
\text { and pollution tracking. }\end{array}$ \\
\hline
\end{tabular}


Table A6. Cont.

\begin{tabular}{|c|c|c|}
\hline Item & Understanding & Acceptance \\
\hline $\begin{array}{l}\text { Enhance the use of data sharing and } \\
\text { digital mobility platforms }\end{array}$ & $\begin{array}{l}\text { I understand the importance of data } \\
\text { sharing and digital mobility platforms. }\end{array}$ & $\begin{array}{l}\text { I am willing to use data sharing and } \\
\text { digital mobility platforms. }\end{array}$ \\
\hline $\begin{array}{l}\text { Establish demand-based ridesharing } \\
\text { services }\end{array}$ & $\begin{array}{l}\text { I know about on-demand ridesharing } \\
\text { service applications for vans or shuttle } \\
\text { buses, trains, Grab, or SOCAR. }\end{array}$ & $\begin{array}{l}\text { I use on-demand ridesharing service } \\
\text { applications for vans or shuttle buses, } \\
\text { trains, Grab, or SOCAR services. }\end{array}$ \\
\hline $\begin{array}{l}\text { Utilize AI and sensor-based predictive } \\
\text { maintenance for the public transport fleet } \\
\text { and infrastructure }\end{array}$ & $\begin{array}{l}\text { I understand the use of AI (Artificial } \\
\text { Intelligence) and sensor-based } \\
\text { maintenance forecasting for the public } \\
\text { transportation infrastructure and traffic. }\end{array}$ & $\begin{array}{l}\text { I agree that AI and sensor-based forecast } \\
\text { maintenance for the public transport } \\
\text { infrastructure is required so that forecast } \\
\text { maintenance can take place before } \\
\text { damage and disruption occurs. }\end{array}$ \\
\hline $\begin{array}{l}\text { Enhance the dynamic smart parking } \\
\text { infrastructure }\end{array}$ & $\begin{array}{l}\text { I know about dynamic smart parking } \\
\text { infrastructures, like smart parking meters } \\
\text { and apps that provide real-time parking } \\
\text { vacancy information. }\end{array}$ & $\begin{array}{l}\text { I use smart parking infrastructure, such } \\
\text { as smart parking meters and apps that } \\
\text { provide real-time parking vacancy } \\
\text { information. }\end{array}$ \\
\hline Establish an electric vehicle revolution & $\begin{array}{l}\text { I understand the importance and } \\
\text { necessity of the electric vehicle } \\
\text { revolution. }\end{array}$ & $\begin{array}{l}\text { I have used electric cars/green } \\
\text { vehicles/energy-efficient } \\
\text { vehicles/electric buses. }\end{array}$ \\
\hline $\begin{array}{l}\text { Enhance collaboration with academia on } \\
\text { R\&D into, and the commercialization of, } \\
\text { EVs and next-generation automobile }\end{array}$ & $\begin{array}{l}\text { I understand the importance of } \\
\text { collaborating with academics and the } \\
\text { private sector in R\&D into, and the } \\
\text { commercialization of, next-generation } \\
\text { electric vehicles and cars. }\end{array}$ & $\begin{array}{l}\text { I am willing to work with academics and } \\
\text { the private sector on the framework, } \\
\text { testing, and regulation of autonomous } \\
\text { vehicles/long-term transit planning. }\end{array}$ \\
\hline $\begin{array}{l}\text { Promote the usage of public transport } \\
\text { applications }\end{array}$ & $\begin{array}{l}\text { I know about applications regarding } \\
\text { travel on public transport services such } \\
\text { as buses, trains, or taxis. }\end{array}$ & $\begin{array}{l}\text { I use applications regarding travel on } \\
\text { public transport services such as buses, } \\
\text { trains or taxis. }\end{array}$ \\
\hline
\end{tabular}

Table A7. Domain 7: Smart Digital Infrastructure.

\begin{tabular}{|c|c|c|}
\hline Item & Understanding & Acceptance \\
\hline $\begin{array}{l}\text { Enhance the roles of service providers in } \\
\text { developing digital infrastructure }\end{array}$ & $\begin{array}{l}\text { I am confident that the infrastructure } \\
\text { sharing policy among service providers } \\
\text { will provide better high-speed internet } \\
\text { services. }\end{array}$ & $\begin{array}{l}\text { I understand that the role of completing } \\
\text { the communication infrastructure of a } \\
\text { new development project is the } \\
\text { responsibility of the developer. }\end{array}$ \\
\hline Enhance internet speed and connectivity & $\begin{array}{l}\text { I know that the government will enforce } \\
\text { minimum internet speed standards in } \\
\text { stages. }\end{array}$ & $\begin{array}{l}\text { I am aware that most major cities in } \\
\text { Malaysia are equipped with } 4 \mathrm{G} \\
\text { high-speed internet facilities. }\end{array}$ \\
\hline $\begin{array}{l}\text { Enhance the government's role in } \\
\text { facilitating the development of } \\
\text { communication infrastructure }\end{array}$ & $\begin{array}{l}\text { I understand that the government always } \\
\text { assists service providers in facilitating the } \\
\text { development of communication } \\
\text { infrastructure. }\end{array}$ & $\begin{array}{l}\text { I believe that the Malaysian Commission } \\
\text { of Communications and Multimedia } \\
\text { (MCMC) should enforce the appropriate } \\
\text { standards for network services. }\end{array}$ \\
\hline $\begin{array}{l}\text { Enhance indoor and outdoor network } \\
\text { coverage }\end{array}$ & $\begin{array}{l}\text { I agree that development companies need } \\
\text { to equip new development projects with } \\
\text { fiber optic lines to support the Smart City } \\
\text { policy. }\end{array}$ & $\begin{array}{l}\text { I agree that new buildings are equipped } \\
\text { with in-building fiber optic network } \\
\text { access facilities. }\end{array}$ \\
\hline $\begin{array}{l}\text { Strengthen policies related to personal } \\
\text { data protection }\end{array}$ & $\begin{array}{l}\text { I am confident that the personal } \\
\text { information of internet users is protected } \\
\text { by the Personal Protection Act } 2010 .\end{array}$ & $\begin{array}{l}\text { I am sure that the reduction of cyber } \\
\text { threats will have a positive impact on the } \\
\text { government, companies and individuals. }\end{array}$ \\
\hline $\begin{array}{l}\text { Strengthen policies related to } \\
\text { cybersecurity }\end{array}$ & $\begin{array}{l}\text { I understand that online systems and } \\
\text { information are safe from cyber-attacks. }\end{array}$ & $\begin{array}{l}\text { I feel that policies and laws related to } \\
\text { cybersecurity and personal data need to } \\
\text { be updated periodically to protect } \\
\text { consumers. }\end{array}$ \\
\hline
\end{tabular}




\section{Appendix B. Fuzzy Delphi Analysis Results}

Table A8. Domain 1: Smart Economy (Understanding).

\begin{tabular}{|c|c|c|c|c|c|c|c|c|}
\hline \multirow[b]{2}{*}{ No. } & \multicolumn{2}{|c|}{ Triangular Fuzzy Number } & \multicolumn{4}{|c|}{ Defuzzification Process } & \multirow[b]{2}{*}{ Result } & \multirow{2}{*}{$\begin{array}{l}\text { Ranking } \\
\text { according to the } \\
\text { Fuzzy Score }\end{array}$} \\
\hline & $\begin{array}{l}\text { Threshold } \\
\text { (d) Value }\end{array}$ & $\begin{array}{c}\text { Expert } \\
\text { Agreement (\%) }\end{array}$ & $m_{1}$ & $m_{2}$ & $m_{3}$ & $\begin{array}{c}\text { Average of } \\
\text { Fuzzy Score }\end{array}$ & & \\
\hline 1 & 0.067 & $88 \%$ & 0.575 & 0.775 & 0.975 & 0.775 & Accepted & 1 \\
\hline 2 & 0.107 & $78 \%$ & 0.555 & 0.755 & 0.955 & 0.755 & Accepted & 2 \\
\hline 3 & 0.210 & $33 \%$ & 0.455 & 0.655 & 0.855 & 0.655 & Rejected & 7 \\
\hline 4 & 0.130 & $78 \%$ & 0.545 & 0.745 & 0.945 & 0.745 & Accepted & 3 \\
\hline 5 & 0.193 & $88 \%$ & 0.490 & 0.690 & 0.890 & 0.690 & Accepted & 6 \\
\hline 6 & 0.156 & $98 \%$ & 0.515 & 0.715 & 0.915 & 0.715 & Accepted & 5 \\
\hline 7 & 0.133 & $73 \%$ & 0.540 & 0.740 & 0.940 & 0.740 & Rejected & 4 \\
\hline
\end{tabular}

Table A9. Domain 1: Smart Economy (Acceptance).

\begin{tabular}{|c|c|c|c|c|c|c|c|c|}
\hline \multirow[b]{2}{*}{ No. } & \multicolumn{2}{|c|}{ Triangular Fuzzy Number } & \multicolumn{4}{|c|}{ Defuzzification Process } & \multirow[b]{2}{*}{ Result } & \multirow{2}{*}{$\begin{array}{l}\text { Ranking } \\
\text { according to the } \\
\text { Fuzzy Score }\end{array}$} \\
\hline & $\begin{array}{l}\text { Threshold } \\
\text { (d) Value }\end{array}$ & $\begin{array}{c}\text { Expert } \\
\text { Agreement (\%) }\end{array}$ & $m_{1}$ & $m_{2}$ & $m_{3}$ & $\begin{array}{c}\text { Average of } \\
\text { Fuzzy Score }\end{array}$ & & \\
\hline 1 & 0.080 & $88 \%$ & 0.570 & 0.770 & 0.970 & 0.770 & Accepted & 1 \\
\hline 2 & 0.130 & $78 \%$ & 0.545 & 0.745 & 0.945 & 0.745 & Accepted & 3 \\
\hline 3 & 0.179 & $90 \%$ & 0.510 & 0.710 & 0.910 & 0.710 & Accepted & 7 \\
\hline 4 & 0.156 & $98 \%$ & 0.515 & 0.715 & 0.915 & 0.715 & Accepted & 4 \\
\hline 5 & 0.158 & $98 \%$ & 0.510 & 0.710 & 0.910 & 0.710 & Accepted & 6 \\
\hline 6 & 0.156 & $98 \%$ & 0.515 & 0.715 & 0.915 & 0.715 & Accepted & 4 \\
\hline 7 & 0.115 & $75 \%$ & 0.550 & 0.750 & 0.950 & 0.750 & Accepted & 2 \\
\hline
\end{tabular}

Table A10. Domain 2: Smart Living (Understanding).

\begin{tabular}{|c|c|c|c|c|c|c|c|c|}
\hline \multirow[b]{2}{*}{ No. } & \multicolumn{2}{|c|}{ Triangular Fuzzy Number } & \multicolumn{4}{|c|}{ Defuzzification Process } & \multirow[b]{2}{*}{ Result } & \multirow{2}{*}{$\begin{array}{l}\text { Ranking } \\
\text { according to the } \\
\text { Fuzzy Score }\end{array}$} \\
\hline & $\begin{array}{l}\text { Threshold } \\
\text { (d) Value }\end{array}$ & $\begin{array}{c}\text { Expert } \\
\text { Agreement (\%) }\end{array}$ & $m_{1}$ & $m_{2}$ & $m_{3}$ & $\begin{array}{l}\text { Average of } \\
\text { Fuzzy Score }\end{array}$ & & \\
\hline 1 & 0.206 & $35 \%$ & 0.420 & 0.620 & 0.820 & 0.620 & Rejected & 5 \\
\hline 2 & 0.101 & $83 \%$ & 0.560 & 0.760 & 0.960 & 0.760 & Accepted & 2 \\
\hline 3 & 0.171 & $81 \%$ & 0.41 & 0.78 & 0.87 & 0.687 & Accepted & 4 \\
\hline 4 & 0.113 & $83 \%$ & 0.555 & 0.755 & 0.955 & 0.755 & Accepted & 3 \\
\hline 5 & 0.069 & $90 \%$ & 0.575 & 0.775 & 0.975 & 0.775 & Accepted & 1 \\
\hline
\end{tabular}

Table A11. Domain 2: Smart Living (Acceptance).

\begin{tabular}{|c|c|c|c|c|c|c|c|c|}
\hline \multirow[b]{2}{*}{ No. } & \multicolumn{2}{|c|}{ Triangular Fuzzy Number } & \multicolumn{4}{|c|}{ Defuzzification Process } & \multirow[b]{2}{*}{ Result } & \multirow{2}{*}{$\begin{array}{l}\text { Ranking } \\
\text { according to the } \\
\text { Fuzzy Score }\end{array}$} \\
\hline & $\begin{array}{l}\text { Threshold } \\
\text { (d) Value }\end{array}$ & $\begin{array}{c}\text { Expert } \\
\text { Agreement (\%) }\end{array}$ & $m_{1}$ & $m_{2}$ & $m_{3}$ & $\begin{array}{c}\text { Average of } \\
\text { Fuzzy Score }\end{array}$ & & \\
\hline 1 & 0.179 & $90 \%$ & 0.470 & 0.670 & 0.870 & 0.670 & Accepted & 5 \\
\hline 2 & 0.183 & $90 \%$ & 0.500 & 0.700 & 0.900 & 0.700 & Accepted & 3 \\
\hline 3 & 0.165 & $85 \%$ & 0.492 & 0.824 & 0.741 & 0.686 & Accepted & 4 \\
\hline 4 & 0.155 & $95 \%$ & 0.525 & 0.725 & 0.925 & 0.725 & Accepted & 1 \\
\hline 5 & 0.172 & $93 \%$ & 0.510 & 0.710 & 0.910 & 0.710 & Accepted & 2 \\
\hline
\end{tabular}

Table A12. Domain 3: Smart Environment (Understanding).

\begin{tabular}{|c|c|c|c|c|c|c|c|c|}
\hline \multirow[b]{2}{*}{ No. } & \multicolumn{2}{|c|}{ Triangular Fuzzy Number } & \multicolumn{4}{|c|}{ Defuzzification Process } & \multirow[b]{2}{*}{ Result } & \multirow{2}{*}{$\begin{array}{l}\text { Ranking } \\
\text { according to the } \\
\text { Fuzzy Score }\end{array}$} \\
\hline & $\begin{array}{l}\text { Threshold } \\
\text { (d) Value }\end{array}$ & $\begin{array}{c}\text { Expert } \\
\text { Agreement (\%) }\end{array}$ & $m_{1}$ & $m_{2}$ & $m_{3}$ & $\begin{array}{l}\text { Average of } \\
\text { Fuzzy Score }\end{array}$ & & \\
\hline 1 & 0.242 & $35 \%$ & 0.375 & 0.570 & 0.770 & 0.572 & Rejected & 9 \\
\hline 2 & 0.128 & $70 \%$ & 0.540 & 0.740 & 0.940 & 0.740 & Rejected & 2 \\
\hline 3 & 0.214 & $35 \%$ & 0.425 & 0.625 & 0.825 & 0.625 & Rejected & 5 \\
\hline 4 & 0.122 & $73 \%$ & 0.545 & 0.745 & 0.945 & 0.745 & Rejected & 1 \\
\hline 5 & 0.155 & $93 \%$ & 0.530 & 0.730 & 0.930 & 0.730 & Accepted & 3 \\
\hline 6 & 0.193 & $90 \%$ & 0.490 & 0.690 & 0.890 & 0.690 & Accepted & 4 \\
\hline 7 & 0.244 & $23 \%$ & 0.400 & 0.600 & 0.800 & 0.600 & Rejected & 6 \\
\hline 8 & 0.201 & $48 \%$ & 0.390 & 0.585 & 0.785 & 0.587 & Rejected & 8 \\
\hline 9 & 0.204 & $45 \%$ & 0.400 & 0.590 & 0.790 & 0.593 & Rejected & 7 \\
\hline
\end{tabular}


Table A13. Domain 3: Smart Environment (Acceptance).

\begin{tabular}{|c|c|c|c|c|c|c|c|c|}
\hline \multirow[b]{2}{*}{ No. } & \multicolumn{2}{|c|}{ Triangular Fuzzy Number } & \multicolumn{4}{|c|}{ Defuzzification Process } & \multirow[b]{2}{*}{ Result } & \multirow{2}{*}{$\begin{array}{l}\text { Ranking } \\
\text { according to the } \\
\text { Fuzzy Score }\end{array}$} \\
\hline & $\begin{array}{l}\text { Threshold } \\
\text { (d) Value }\end{array}$ & $\begin{array}{c}\text { Expert } \\
\text { Agreement (\%) }\end{array}$ & $m_{1}$ & $m_{2}$ & $m_{3}$ & $\begin{array}{c}\text { Average of } \\
\text { Fuzzy Score }\end{array}$ & & \\
\hline 1 & 0.174 & $50 \%$ & 0.425 & 0.625 & 0.825 & 0.625 & Rejected & 6 \\
\hline 2 & 0.233 & $33 \%$ & 0.395 & 0.590 & 0.790 & 0.592 & Rejected & 7 \\
\hline 3 & 0.219 & $35 \%$ & 0.445 & 0.640 & 0.840 & 0.642 & Rejected & 4 \\
\hline 4 & 0.260 & $38 \%$ & 0.380 & 0.570 & 0.770 & 0.573 & Rejected & 8 \\
\hline 5 & 0.189 & $88 \%$ & 0.505 & 0.705 & 0.905 & 0.705 & Accepted & 2 \\
\hline 6 & 0.181 & $90 \%$ & 0.505 & 0.705 & 0.905 & 0.705 & Accepted & 2 \\
\hline 7 & 0.256 & $38 \%$ & 0.360 & 0.555 & 0.755 & 0.557 & Rejected & 9 \\
\hline 8 & 0.246 & $30 \%$ & 0.435 & 0.630 & 0.830 & 0.632 & Rejected & 5 \\
\hline 9 & 0.153 & $98 \%$ & 0.520 & 0.720 & 0.920 & 0.720 & Accepted & 1 \\
\hline
\end{tabular}

Table A14. Domain 4: Smart People (Understanding).

\begin{tabular}{|c|c|c|c|c|c|c|c|c|}
\hline \multirow[b]{2}{*}{ No. } & \multicolumn{2}{|c|}{ Triangular Fuzzy Number } & \multicolumn{4}{|c|}{ Defuzzification Process } & \multirow[b]{2}{*}{ Result } & \multirow{2}{*}{$\begin{array}{l}\text { Ranking } \\
\text { according to the } \\
\text { Fuzzy Score }\end{array}$} \\
\hline & $\begin{array}{l}\text { Threshold } \\
\text { (d) Value }\end{array}$ & $\begin{array}{c}\text { Expert } \\
\text { Agreement (\%) }\end{array}$ & $m_{1}$ & $m_{2}$ & $m_{3}$ & $\begin{array}{c}\text { Average of } \\
\text { Fuzzy Score }\end{array}$ & & \\
\hline 1 & 0.088 & $83 \%$ & 0.565 & 0.765 & 0.965 & 0.765 & Accepted & 1 \\
\hline 2 & 0.107 & $78 \%$ & 0.555 & 0.755 & 0.955 & 0.755 & Accepted & 2 \\
\hline 3 & 0.133 & $73 \%$ & 0.540 & 0.740 & 0.940 & 0.740 & Rejected & 5 \\
\hline 4 & 0.122 & $73 \%$ & 0.545 & 0.745 & 0.945 & 0.745 & Rejected & 4 \\
\hline 5 & 0.122 & $80 \%$ & 0.550 & 0.750 & 0.950 & 0.750 & Accepted & 3 \\
\hline 6 & 0.169 & $93 \%$ & 0.515 & 0.715 & 0.915 & 0.715 & Accepted & 6 \\
\hline
\end{tabular}

Table A15. Domain 4: Smart People (Acceptance).

\begin{tabular}{|c|c|c|c|c|c|c|c|c|}
\hline \multirow[b]{2}{*}{ No. } & \multicolumn{2}{|c|}{ Triangular Fuzzy Number } & \multicolumn{4}{|c|}{ Defuzzification Process } & \multirow[b]{2}{*}{ Result } & \multirow{2}{*}{$\begin{array}{l}\text { Ranking } \\
\text { according to the } \\
\text { Fuzzy Score }\end{array}$} \\
\hline & $\begin{array}{l}\text { Threshold } \\
\text { (d) Value }\end{array}$ & $\begin{array}{c}\text { Expert } \\
\text { Agreement (\%) }\end{array}$ & $m_{1}$ & $m_{2}$ & $m_{3}$ & $\begin{array}{l}\text { Average of } \\
\text { Fuzzy Score }\end{array}$ & & \\
\hline 1 & 0.110 & $80 \%$ & 0.555 & 0.755 & 0.955 & 0.755 & Accepted & 2 \\
\hline 2 & 0.080 & $88 \%$ & 0.570 & 0.770 & 0.970 & 0.770 & Accepted & 1 \\
\hline 3 & 0.128 & $70 \%$ & 0.540 & 0.740 & 0.940 & 0.740 & Rejected & 3 \\
\hline 4 & 0.133 & $73 \%$ & 0.540 & 0.740 & 0.940 & 0.740 & Rejected & 3 \\
\hline 5 & 0.150 & $95 \%$ & 0.530 & 0.730 & 0.930 & 0.730 & Accepted & 5 \\
\hline 6 & 0.165 & $93 \%$ & 0.520 & 0.720 & 0.920 & 0.720 & Accepted & 6 \\
\hline
\end{tabular}

Table A16. Domain 5: Smart Government (Understanding).

\begin{tabular}{|c|c|c|c|c|c|c|c|c|}
\hline \multirow[b]{2}{*}{ No. } & \multicolumn{2}{|c|}{ Triangular Fuzzy Number } & \multicolumn{4}{|c|}{ Defuzzification Process } & \multirow[b]{2}{*}{ Result } & \multirow{2}{*}{$\begin{array}{l}\text { Ranking } \\
\text { according to the } \\
\text { Fuzzy Score }\end{array}$} \\
\hline & $\begin{array}{l}\text { Threshold } \\
\text { (d) Value }\end{array}$ & $\begin{array}{c}\text { Expert } \\
\text { Agreement (\%) }\end{array}$ & $m_{1}$ & $m_{2}$ & $m_{3}$ & $\begin{array}{c}\text { Average of } \\
\text { Fuzzy Score }\end{array}$ & & \\
\hline 1 & 0.182 & $95 \%$ & 0.505 & 0.700 & 0.900 & 0.702 & Accepted & 2 \\
\hline 2 & 0.192 & $90 \%$ & 0.495 & 0.695 & 0.895 & 0.695 & Accepted & 3 \\
\hline 3 & 0.224 & $88 \%$ & 0.500 & 0.690 & 0.890 & 0.693 & Rejected & 4 \\
\hline 4 & 0.155 & $95 \%$ & 0.525 & 0.725 & 0.925 & 0.725 & Accepted & 1 \\
\hline
\end{tabular}

Table A17. Domain 5: Smart Government (Acceptance).

\begin{tabular}{|c|c|c|c|c|c|c|c|c|}
\hline \multirow[b]{2}{*}{ No. } & \multicolumn{2}{|c|}{ Triangular Fuzzy Number } & \multicolumn{4}{|c|}{ Defuzzification Process } & \multirow[b]{2}{*}{ Result } & \multirow{2}{*}{$\begin{array}{l}\text { Ranking } \\
\text { according to the } \\
\text { Fuzzy Score }\end{array}$} \\
\hline & $\begin{array}{l}\text { Threshold } \\
\text { (d) Value }\end{array}$ & $\begin{array}{c}\text { Expert } \\
\text { Agreement (\%) }\end{array}$ & $m_{1}$ & $m_{2}$ & $m_{3}$ & $\begin{array}{l}\text { Average of } \\
\text { Fuzzy Score }\end{array}$ & & \\
\hline 1 & 0.176 & $95 \%$ & 0.495 & 0.695 & 0.895 & 0.695 & Accepted & 3 \\
\hline 2 & 0.169 & $93 \%$ & 0.515 & 0.715 & 0.915 & 0.715 & Accepted & 1 \\
\hline 3 & 0.202 & $85 \%$ & 0.480 & 0.680 & 0.880 & 0.680 & Rejected & 4 \\
\hline 4 & 0.191 & $90 \%$ & 0.500 & 0.700 & 0.900 & 0.700 & Accepted & 2 \\
\hline
\end{tabular}


Table A18. Domain 6: Smart Mobility (Understanding).

\begin{tabular}{|c|c|c|c|c|c|c|c|c|}
\hline \multirow[b]{2}{*}{ No. } & \multicolumn{2}{|c|}{ Triangular Fuzzy Number } & \multicolumn{4}{|c|}{ Defuzzification Process } & \multirow[b]{2}{*}{ Result } & \multirow{2}{*}{$\begin{array}{l}\text { Ranking } \\
\text { according to the } \\
\text { Fuzzy Score }\end{array}$} \\
\hline & $\begin{array}{l}\text { Threshold } \\
\text { (d) Value }\end{array}$ & $\begin{array}{c}\text { Expert } \\
\text { Agreement (\%) }\end{array}$ & $m_{1}$ & $m_{2}$ & $m_{3}$ & $\begin{array}{c}\text { Average of } \\
\text { Fuzzy Score }\end{array}$ & & \\
\hline 1 & 0.137 & $75 \%$ & 0.540 & 0.740 & 0.940 & 0.740 & Accepted & 3 \\
\hline 2 & 0.130 & $78 \%$ & 0.545 & 0.745 & 0.945 & 0.745 & Accepted & 2 \\
\hline 3 & 0.113 & $83 \%$ & 0.555 & 0.755 & 0.955 & 0.755 & Accepted & 1 \\
\hline 4 & 0.209 & $85 \%$ & 0.495 & 0.695 & 0.895 & 0.695 & Rejected & 7 \\
\hline 5 & 0.147 & $80 \%$ & 0.540 & 0.740 & 0.940 & 0.740 & Accepted & 3 \\
\hline 6 & 0.220 & $85 \%$ & 0.485 & 0.685 & 0.885 & 0.685 & Rejected & 8 \\
\hline 7 & 0.175 & $90 \%$ & 0.515 & 0.715 & 0.915 & 0.715 & Accepted & 6 \\
\hline 8 & 0.177 & $90 \%$ & 0.520 & 0.720 & 0.920 & 0.720 & Accepted & 5 \\
\hline
\end{tabular}

Table A19. Domain 6: Smart Mobility (Acceptance).

\begin{tabular}{|c|c|c|c|c|c|c|c|c|}
\hline \multirow[b]{2}{*}{ No. } & \multicolumn{2}{|c|}{ Triangular Fuzzy Number } & \multicolumn{4}{|c|}{ Defuzzification Process } & \multirow[b]{2}{*}{ Result } & \multirow{2}{*}{$\begin{array}{l}\text { Ranking } \\
\text { according to the } \\
\text { Fuzzy Score }\end{array}$} \\
\hline & $\begin{array}{l}\text { Threshold } \\
\text { (d) Value }\end{array}$ & $\begin{array}{c}\text { Expert } \\
\text { Agreement (\%) }\end{array}$ & $m_{1}$ & $m_{2}$ & $m_{3}$ & $\begin{array}{c}\text { Average of } \\
\text { Fuzzy Score }\end{array}$ & & \\
\hline 1 & 0.311 & $20 \%$ & 0.390 & 0.590 & 0.790 & 0.590 & Rejected & 7 \\
\hline 2 & 0.184 & $90 \%$ & 0.485 & 0.685 & 0.885 & 0.685 & Accepted & 4 \\
\hline 3 & 0.227 & $80 \%$ & 0.490 & 0.690 & 0.890 & 0.690 & Rejected & 3 \\
\hline 4 & 0.176 & $93 \%$ & 0.500 & 0.700 & 0.900 & 0.700 & Accepted & 1 \\
\hline 5 & 0.245 & $25 \%$ & 0.465 & 0.660 & 0.860 & 0.662 & Rejected & 5 \\
\hline 6 & 0.346 & $25 \%$ & 0.380 & 0.555 & 0.755 & 0.563 & Rejected & 8 \\
\hline 7 & 0.200 & $93 \%$ & 0.495 & 0.690 & 0.890 & 0.692 & Accepted & 2 \\
\hline 8 & 0.273 & $20 \%$ & 0.460 & 0.650 & 0.850 & 0.653 & Rejected & 6 \\
\hline
\end{tabular}

Table A20. Domain 7: Smart Digital Infrastructure (Understanding).

\begin{tabular}{|c|c|c|c|c|c|c|c|c|}
\hline \multirow[b]{2}{*}{ No. } & \multicolumn{2}{|c|}{ Triangular Fuzzy Number } & \multicolumn{4}{|c|}{ Defuzzification Process } & \multirow[b]{2}{*}{ Result } & \multirow{2}{*}{$\begin{array}{l}\text { Ranking } \\
\text { according to the } \\
\text { Fuzzy Score }\end{array}$} \\
\hline & $\begin{array}{l}\text { Threshold } \\
\text { (d) Value }\end{array}$ & $\begin{array}{c}\text { Expert } \\
\text { Agreement (\%) }\end{array}$ & $m_{1}$ & $m_{2}$ & $m_{3}$ & $\begin{array}{c}\text { Average of } \\
\text { Fuzzy Score }\end{array}$ & & \\
\hline 1 & 0.165 & $95 \%$ & 0.530 & 0.725 & 0.925 & 0.727 & Accepted & 2 \\
\hline 2 & 0.217 & $85 \%$ & 0.495 & 0.690 & 0.890 & 0.692 & Accepted & 3 \\
\hline 3 & 0.191 & $93 \%$ & 0.485 & 0.680 & 0.880 & 0.682 & Accepted & 4 \\
\hline 4 & 0.144 & $73 \%$ & 0.535 & 0.735 & 0.935 & 0.735 & Rejected & 1 \\
\hline 5 & 0.214 & $30 \%$ & 0.460 & 0.660 & 0.860 & 0.660 & Rejected & 5 \\
\hline 6 & 0.291 & $58 \%$ & 0.330 & 0.520 & 0.720 & 0.523 & Rejected & 6 \\
\hline
\end{tabular}

Table A21. Domain 7: Smart Digital Infrastructure (Acceptance).

\begin{tabular}{|c|c|c|c|c|c|c|c|c|}
\hline \multirow[b]{2}{*}{ No. } & \multicolumn{2}{|c|}{ Triangular Fuzzy Number } & \multicolumn{4}{|c|}{ Defuzzification Process } & \multirow[b]{2}{*}{ Result } & \multirow{2}{*}{$\begin{array}{l}\text { Ranking } \\
\text { according to the } \\
\text { Fuzzy Score }\end{array}$} \\
\hline & $\begin{array}{l}\text { Threshold } \\
\text { (d) Value }\end{array}$ & $\begin{array}{c}\text { Expert } \\
\text { Agreement (\%) }\end{array}$ & $m_{1}$ & $m_{2}$ & $m_{3}$ & $\begin{array}{c}\text { Average of } \\
\text { Fuzzy Score }\end{array}$ & & \\
\hline 1 & 0.221 & $33 \%$ & 0.455 & 0.655 & 0.855 & 0.655 & Rejected & 6 \\
\hline 2 & 0.202 & $90 \%$ & 0.490 & 0.690 & 0.890 & 0.690 & Rejected & 5 \\
\hline 3 & 0.110 & $80 \%$ & 0.555 & 0.755 & 0.955 & 0.755 & Accepted & 2 \\
\hline 4 & 0.101 & $83 \%$ & 0.560 & 0.760 & 0.960 & 0.760 & Accepted & 1 \\
\hline 5 & 0.134 & $80 \%$ & 0.545 & 0.745 & 0.945 & 0.745 & Accepted & 3 \\
\hline 6 & 0.134 & $80 \%$ & 0.545 & 0.745 & 0.945 & 0.745 & Accepted & 3 \\
\hline
\end{tabular}

Note: Three conditions to accept an item: threshold value $(d) \leq 0.2$, percentage of experts' consensus $\geq 75 \%$, and average fuzzy score $\left(A_{\max }\right) \geq \alpha-$ cut value $=0.5$.

\section{References}

1. De Souza, K.C.; Hunter, M.; Jacob, B.; Yigitcanlar, T. Pathways to the Making of Prosperous Smart Cities: An Exploratory Study on the Best Practice. J. Urban Technol. 2020, 27, 3-32. [CrossRef]

2. Giffinger, R.; Fertner, C.; Kramar, H.; Kalasek, R.; Pichler, N.; Meijers, E. Smart Cities: Ranking of European Medium-Sized Cities; TU Vienna: Wien, Astria, 2007.

3. Cohen, B. What Exactly Is a Smart City? Available online: https://www.fastcodesign.com/1680538/what-exactly-is-a-smart-city (accessed on 8 August 2017). 
4. Chourabi, H.; Nam, T.; Walker, S.; Gil-Garcia, J.R.; Mellouli, S.; Nahon, K.; Pardo, T.A.; Scholl, H.J. Understanding smart cities: An integrative framework. In Proceedings of the 45th Hawaii International Conference on System Sciences Understanding (ICSS), Maui, HI, USA, 4-7 January 2012; IEEE: Piscataway, NJ, USA, 2012; pp. 2289-2297.

5. Alonso, R.G.; Castro, S.L. Technology helps, people make: A smart city governance framework grounded in deliberative democracy. In Smarter as the New Urban Agenda; A Comprehensive View of the 21st Century City; Gil-Garcia, J.R., Pardo, T.A., Nam, T., Eds.; Springer: Cham, Switzerland, 2016; pp. 333-347.

6. Mosannenzadeh, F.; Vettorato, D. Defining Smart City. A Conceptual Framework Based on Keyword Analysis. TeMA J. Land Use Mobil. Environ. 2014, 6, 683-694. [CrossRef]

7. Anthopoulos, L.; Janssen, M.; Weerakkody, V. A Unified Smart City Model (USCM) for Smart City Conceptualization and Benchmarking. Int. J. Electron. Gov. Res. 2016, 12, 77-93. [CrossRef]

8. Hong Kong. Hong Kong Smart City Blueprint. Available online: https://www.smartcity.gov.hk/doc/HongKongSmartCityBlueprint(EN) .pdf (accessed on 2 February 2020).

9. Ministry of Housing and Local Government. Malaysia Smart City Framework; Ministry of Housing and Local Government: Putrajaya, Malaysia, 2019.

10. Lombardi, P.; Giordano, S.; Farouh, H.; Yousef, W. Modelling the smart city performance. Innov. Eur. J. Soc. Sci. Res. 2012, 25, 137-149. [CrossRef]

11. Tahir, Z.; Malek, J.A. Main criteria in the development of smart cities determined using analytical method. Plan. Malays. J. 2016, 14, 1-14. [CrossRef]

12. Yasmin, M.A.; Hasniyati, H.; Melasutra, M.D.; Md Nasir, D.; Anuar, A. An initiatives-based framework for assessing smart city. Plan Malays. 2016, 14, 13-22.

13. Li, C.; Dai, Z.; Liu, X.; Sun, W. Evaluation system: Evaluation of smart city shareable framework and its applications in China. Sustainability 2020, 12, 2957. [CrossRef]

14. Aghimien, D.O.; Aigbavboa, C.; Edwards, D.J.; Mahamadu, A.-M.; Olomolaiye, P.; Nash, H.; Onyia, M. A fuzzy synthetic evaluation of the challenges of smart city development in developing countries. Smart Sustain. Built Environ. 2020. [CrossRef]

15. Sharifi, A. A typology of smart city assessment tools and indicator sets. Sustain. Cities Soc. 2020, 53, 101936. [CrossRef]

16. Institute for Management Development (IMD). Smart City Index; Institute for Management Development and Singapore University of Technology and Design: Singapore, 2019.

17. OECD. Measuring Smart Cities' Performance: Do Smart Cities Benefit Everyone? Organisation for Economic Co-operation and Development: Paris, France, 2020.

18. Caird, S.P.; Hallett, S.H. Towards evaluation design for smart city development. J. Urban Des. 2019, 24, 188-209. [CrossRef]

19. Lim, S.B.; Malek, J.A.; Hashim, N. Implementing the smart city concept in Malaysia: Contemporary challenges, strategies and opportunities in the COVID-19 era. Malays. Townplan J. 2021, 1-20, forthcoming.

20. Vinod Kumar, T.M.; Dahiya, B. Smart economy in smart cities. In Smart Economy in Smart Cities, Advances in 21st Century Human Settlements; Vinod Kumar, T.M., Ed.; Springer: Singapore, 2017; pp. 3-76.

21. Deng, T.; Zhang, K.; Shen, Z.J. A systematic review of a digital twin city: A new pattern of urban governance toward smart cities. J. Manag. Sci. Eng. 2021, 6, 125-134. [CrossRef]

22. Yigitcanlar, T.; Cugurullo, F. The Sustainability of Artificial Intelligence: An Urbanistic Viewpoint from the Lens of Smart and Sustainable Cities. Sustainability 2020, 12, 8548. [CrossRef]

23. British High Commission Kuala Lumpur. Smart City Handbook Malaysia: How Technology and Data Are Shaping the Future of Malaysian Cities; British High Commission Kuala Lumpur: Kuala Lumpur, Malaysia, 2021.

24. Centre for Liveable Cities. ASEAN Smart Cities Network; Centre for Liveable Cities: Singapore, 2018.

25. Low, S.; Ullah, F.; Shirowzhan, S.; Sepasgozar, S.M.E.; Lee, C.L. Smart Digital Marketing Capabilities for Sustainable Property Development: A Case of Malaysia. Sustainability 2020, 12, 5402. [CrossRef]

26. Hasibuan, A.; Sulaiman, O.K. Smart city, konsep kota cerdas sebagai alternatif penyelesaian masalah perkotaan kabupat-en/kota. Bul. Utama Tek. 2019, 14, 127-135.

27. Oxford Business Group. Going Strong: The Shift toward Higher-Value-Added Activities Is Creating New Challenges as well as Prospects. Available online: https:/ / oxfordbusinessgroup.com/overview/going-strong-shift-toward-higher-value-addedactivities-creating-new-challenges-well-prospects (accessed on 27 July 2021).

28. Rana, N.P.; Luthra, S.; Mangla, S.K.; Islam, R.; Roderick, S.; Dwivedi, Y.K. Barriers to the development of smart cities in Indian context. Inf. Syst. Front. 2019, 21, 503-525. [CrossRef]

29. Firmansyah, H.S.; Supangkat, S.H.; Arman, A.A. Studi tentang model pengembangan kota cerdas. In Proceedings of the e-Indonesia Initiatives (eII-Forum), Bandung, Indonesia, 15-16 October 2015; Institut Teknologi Bandung: Bandung, Indonesia, 2015; pp. 42-47.

30. Eden Strategy Institute. Top 50 Smart City Governments; Eden Strategy Institute and Ong\&Ong Pte Ltd.: Singapore, 2018.

31. Diez, T. Personal Fabrication: Fab Labs as Platforms for Citizen-Based Innovation, from Microcontrollers to Cities. Nexus Netw. J. 2012, 14, 457-468. [CrossRef]

32. Monzon, A. Smart cities concept and challenges: Bases for the assessment of smart city projects. In Smartgreens 2015 and Vehits 2015, Communications in Computer and Information Science 579; Helfert, M., Krempels, K.H., Klein, C., Donellan, B., Guiskhin, O., Eds.; Springer: Cham, Switzerland, 2015; pp. 17-31. 
33. Katz, B.; Wagner, J. The Rise of Innovation Districts: A New Geography of Innovation in America; Brookings Metropolitan Policy Program: Washington, DC, USA, 2014.

34. BEA. What Is Industry Value Added? Bureau of Economic Analysis, US Department of Commerce. Available online: https: / / www.bea.gov/faq/index.cfm?faq_id=1842006 (accessed on 24 July 2021).

35. Govada, S.S.; Spruijt, W.; Rodgers, T. Introduction to Hong Kong's Development. In Smart Economy in Smart Cities; Vinod Kumar, T.M., Dahiya, B., Eds.; Springer: Singapore, 2017; pp. 171-186.

36. Lim, S.B.; Yong, C.K.; Malek, J.A.; Jali, M.F.M.; Awang, A.H.; Tahir, Z. Effectiveness of Fear and Crime Prevention Strategy for Sustainability of Safe City. Sustainability 2020, 12, 593. [CrossRef]

37. Alkawsi, G.A.; Ali, N.; Mustafa, A.S.; Baashar, Y.; Alhussian, H.; Alkahtani, A.; Tiong, S.K.; Ekanayake, J. A hybrid SEM-neural network method for identifying acceptance factors of the smart meters in Malaysia: Challenges perspective. Alex. Eng. J. 2021, 60, 227-240. [CrossRef]

38. Hollands, R.G. Beyond the corporate smart city? Glimpses of other possibilities of smartness. In Smart Urbanism: Utopian Vision or False Dawn? Marvin, S., Luque-Ayala, A., McFarlane, C., Eds.; Routledge: London, UK, 2016; pp. 168-184.

39. Anttiroiko, A.-V. Successful government responses to the pandemic: Contextualizing national and urban responses to the COVID-19 outbreak in East and West. Int. J. E-Plan. Res. 2021, 10, 1-17. [CrossRef]

40. Choi, C.; Choi, J.; Kim, C.; Lee, D.; Baek, U.; Sim, Y. The Smart City Evolution in South Korea: Findings from Big Data Analytics. J. Asian Financ. Econ. Bus. 2020, 7, 301-311. [CrossRef]

41. Kashif, M.; Samsi, S.Z.M.; Awang, Z.; Mohamad, M. EXQ: Measurement of healthcare experience quality in Malaysian settings. A contextualist perspective. Int. J. Pharm. Healthc. Mark. 2016, 10, 27-47. [CrossRef]

42. Petrova-Antonova, D.; Ilieva, S. Smart cities evaluation-A survey of performance and sustainability indicators. In Proceedings of the 44th Euromicro Conference on Software Engineering and Advanced Application (SEAA), Prague, Czech Republic, 29-31 August 2018; IEEE: Piscataway, NJ, USA, 2018; pp. 486-493.

43. Yigitcanlar, T.; De Souza, K.; Butler, L.; Roozkhosh, F. Contributions and Risks of Artificial Intelligence (AI) in Building Smarter Cities: Insights from a Systematic Review of the Literature. Energies 2020, 13, 1473. [CrossRef]

44. Smart Selangor Delivery Unit (SSDU). Smart Selangor Action Plan to 2025 (SSAP 2025); Menteri Besar Selangor Inc.: Shah Alam, Malaysia, 2020.

45. PLANMalaysia. Bandar Selamat 2010; PLANMalaysia (Jabatan Perancangan Bandar dan Desa): Kuala Lumpur, Malaysia, 2010.

46. PLANMalaysia. Reka Bentuk Bandar Selamat: Panduan Pelaksanaan. Crime Prevention through Environmental Design (CPTED) Implementation Guide; PLANMalaysia (Jabatan Perancangan Bandar dan Desa): Kuala Lumpur, Malaysia, 2010.

47. Lim, S.B.; Yong, C.K.; Rashid, M.F.A.; Malek, J.A. A framework of challenges facing the safe city programme in Kuala Lumpur. Plan. Malays. 2020, 18, 47-61.

48. Tan-Mullins, M.; Cheshmehzangi, A.; Chien, S.-S.; Xie, L. Smart-Eco Cities in China: Trends and City Profiles 2016; University of Exeter (SMART-ECO Project): Exerter, UK, 2017.

49. Valencia, S.C.; Simon, D.; Croese, S.; Nordqvist, J.; Oloko, M.; Sharma, T.; Buck, N.T.; Versace, I. Adapting the Sustainable Development Goals and the New Urban Agenda to the city level: Initial reflections from a comparative research project. Int. J. Urban Sustain. Dev. 2019, 11, 4-23. [CrossRef]

50. Kundu, D.; Sietchiping, R.; Kinyanjui, M. (Eds.) Developing National Urban Policies: Ways Forward to Green and Smart Cities; Springer: Singapore, 2020.

51. Yigitcanlar, T.; Butler, L.; Windle, E.; DeSouza, K.; Mehmood, R.; Corchado, J. Can Building “Artificially Intelligent Cities" Safeguard Humanity from Natural Disasters, Pandemics, and Other Catastrophes? An Urban Scholar's Perspective. Sensors 2020, 20, 2988. [CrossRef] [PubMed]

52. UN-Habitat. World Cities Report 2020: The Value of Sustainable Urbanization; United Nations Human Settlements Programme: Nairobi, Kenya, 2020.

53. Connolly, C. From resilience to multi-species flourishing: (Re)imagining urban-environmental governance in Penang, Malaysia. Urban Stud. 2019, 57, 1485-1501. [CrossRef]

54. Fong, V. Smart Selangor Blueprint: Selangor Smart Cities? Available online: http:/ /www.smartcitiesasia.com/blueprint-smartcity-selangor / (accessed on 1 February 2018).

55. Yigitcanlar, T.; Teriman, S. Rethinking sustainable urban development: Towards an integrated planning and development process. Int. J. Environ. Sci. Technol. 2015, 12, 341-352. [CrossRef]

56. Qureshi, F. In Malaysia, the Fate of a Peat Forest Relies on a Powerful State Official. Available online: https://www.eco-business. $\mathrm{com} /$ news / in-malaysia-the-fate-of-a-peat-forest-relies-on-a-powerful-state-official/ (accessed on 25 July 2021).

57. Abdullah, M.Y.H.; Pawanteh, L.; Abdullah, S.M.S.; Mustaffa, N. Kesedaran dan sikap komuniti dalam pengurusan perseki-taran di Wilayah Iskandar, Johor. J. Melayu. 2010, 5, 71-86.

58. Hare, R.M. A Philosophical Autobiography. Utilitas 2002, 14, 269-305. [CrossRef]

59. Borhannuddin, M.S. Ungku Aziz's perspective on "development". Turk. J. Islam. Econ. 2015, 2, 1-15. [CrossRef]

60. Tegos, S. Civility and politeness in early modern thought. In Encyclopedia of Early Modern Philosophy and the Sciences; Jalobeanu, D., Wolfe, C.T., Eds.; Springer: Cham, Switzerland, 2021; pp. 1-8.

61. Arnstein, S.R. A Ladder of Citizen Participation. J. Am. Inst. Plan. 1969, 35, 216-224. [CrossRef] 
62. Malek, J.A.; Lim, S.B.; Yigitcanlar, T. Social Inclusion Indicators for Building Citizen-Centric Smart Cities: A Systematic Literature Review. Sustainability 2021, 13, 376. [CrossRef]

63. Rotta, M.J.R.; Sell, D.; dos Santos Pacheco, R.C.; Yigitcanlar, T. Digital Commons and Citizen Coproduction in Smart Cities: Assessment of Brazilian Municipal E-Government Platforms. Energies 2019, 12, 2813. [CrossRef]

64. United Nations (UN). E-Government Survey 2020; Department of Economic and Social Affairs, United Nations: New York, NY, USA, 2020.

65. Yigitcanlar, T.; Kankanamge, N.; Vella, K. How are smart city concepts and technologies perceived and utilized? A systematic geo-Twitter analysis of smart cities in Australia. J. Urban Technol. 2021, 28, 135-154. [CrossRef]

66. Bedi, R.S. Malaysia Embarks on Digitalisation Journey with National 4IR Policy Launch. Available online: https://www.thestar com.my/news/nation/2021/07/01/malaysia-embarks-on-digitalisation-journey-with-national-4ir-policy-launch (accessed on 26 July 2021).

67. Economic Planning Unit. National Fourth Industrial Revolution (4IR) Policy; Economic Planning Unit, Prime Minister's Department: Putrajaya, Malaysia, 2021.

68. Caragliu, A.; del Bo, C.F.; Nijkamp, P. Smart Cities in Europe. J. Urban Technol. 2011, 18, 65-82. [CrossRef]

69. Lim, S.B.; Malek, J.A.; Hussain, M.Y.; Tahir, Z.; Saman, N.H.M. SDGs, smart urbanisation, and politics: Stakeholder partner-ships and environmental cases in Malaysia. J. Sustain. Sci. Manag. 2021, 16, 190-219. [CrossRef]

70. Meijer, A.; Bolívar, M.P.R. Governing the smart city: A review of the literature on smart urban governance. Int. Rev. Adm. Sci. 2016, 82, 392-408. [CrossRef]

71. Vinod Kumar, T.M. (Ed.) E-Governance for Smart Cities. In E-Governance for Smart Cities, Advances in 21st Century Human Settlements; Springer: Singapore, 2015; pp. 1-46.

72. Johnson, P.A.; Acedo, A.; Robinson, P.J. Canadian smart cities: Are we wiring new citizen-local government interactions? Can Geogr. 2020, 64, 402-415. [CrossRef]

73. Lim, S.B.; Malek, J.A.; Hussain, M.Y.; Tahir, Z. Participation in e-government services and smart city programs: A case study of malaysian local authority. Plan. Malays. J. 2020, 18, 300-312. [CrossRef]

74. Meijer, A. Datapolis: A public governance perspective on "smart cities". Perspect. Public Manag. Gov. 2018, 1, 195-206. [CrossRef]

75. Urban Tide. Overview of the Smart Cities Maturity Model: Joining the Dots of Smart Cities; Urban Tide and Scottish Government: Edinburgh, UK, 2014.

76. Komninos, N.; Kakderi, C.; Panori, A.; Tsarchopoulos, P. Smart City Planning from an Evolutionary Perspective. J. Urban Technol. 2019, 26, 3-20. [CrossRef]

77. Purwanto, A.; Zuiderwijk, A.; Janssen, M. Citizen engagement with open government data: A systematic literature review of drivers and inhibitors. Int. J. Electron. Gov. Res. 2020, 16, 1-25. [CrossRef]

78. Yigitcanlar, T.; Han, H.; Kamruzzaman, M.; Ioppolo, G.; Sabatini-Marques, J. The making of smart cities: Are Songdo, Masdar, Amsterdam, San Francisco and Brisbane the best we could build? Land Use Policy 2019, 88, 104187. [CrossRef]

79. Yigitcanlar, T. Smart city policies revisited: Considerations for a truly smart and sustainable urbanism practice. World Technop. Rev. 2018, 7, 97-112.

80. Thestar. Smart City Players Working in Silos Hindering Development as a Whole, Says Dr M. Available online: https: / / www.thestar.com.my/news/nation/2019/09/23/smart-city-players-working-in-silos-hindering-development-as-a-wholesays-dr-m (accessed on 2 February 2021).

81. Idrus, N.A.; Ismail, S.; Sanusi, F.A. Delays in Malaysian government projects: Learning from project management failure. Jurutera 2019, 10, 13-19.

82. Ramli, H. Birokrasi Jejas Sistem Penyampaian. Available online: https://www.mef.org.my/MEFITN/utusan070209a.pdf (accessed on 20 July 2021).

83. Trombin, M.; Pinna, R.; Musso, M.; Magnaghi, E.; De Marco, M. Mobility management: From traditional to people-centric approach in the smart city. In Emerging Technologies for Connected Internet of Vehicles and Intelligent Transportation System Networks, Studies in Systems, Decision and Control 242; Elhoseny, M., Hassanien, E., Eds.; Springer: Cham, Switzerland, 2020 ; pp. 165-182.

84. Yigitcanlar, T.; Kamruzzaman, M. Smart Cities and Mobility: Does the Smartness of Australian Cities Lead to Sustainable Commuting Patterns? J. Urban Technol. 2019, 26, 21-46. [CrossRef]

85. Asirvatham, D.; Brohi, S.N.; Xion, T.E.; Theng, T.G.; Fei, N.J.; Kaur, S.; Pillai, T.R.; Sukumaran, S.; Yue, W.S.; Wei, G.; et al. Smart Mobility Cities: Connecting Bristol and Kuala Lumpur Project Report; University of Bristol: Bristol, UK, 2018.

86. D'Amico, G.; L'Abbate, P.; Liao, W.; Yigitcanlar, T.; Ioppolo, G. Understanding Sensor Cities: Insights from Technology Giant Company Driven Smart Urbanism Practices. Sensors 2020, 20, 4391. [CrossRef] [PubMed]

87. Walker, A. Safe Streets Are the Best Tool We Have to Combat Climate Change and We Need to Act Now. Available online: https:/ / www.curbed.com/2018/10/10/17957532/climate-change-street-design-vision-zero (accessed on 14 March 2020).

88. NYC Mayor's Office. Building a Smart + Equitable City; NYC Mayor's Office of Tech + Innovation: New York, NY, USA, 2015.

89. Sarkar, A. Smart Cities: A Futuristic Vision. Available online: https://www.thesmartcityjournal.com/en/articles/1333-smartcities-futuristic-vision (accessed on 26 July 2021).

90. Frost and Sullivan. Smart Cities—Frost \& Sullivan Value Proposition. Available online: https://www.frost.com/wp-content/ uploads/2019/01/SmartCities.pdf (accessed on 5 August 2021). 
91. Dirks, S.; Keeling, M. A Vision of Smarter Cities: How Cities Can Lead Way into a Prosperous and Sustainable Future; International Business Machines Corporation: New York, NY, USA, 2009.

92. Praharaj, S.; Han, J.H.; Hawken, S. Innovative Civic Engagement and Digital Urban Infrastructure: Lessons from 100 Smart Cities Mission in India. Procedia Eng. 2017, 180, 1423-1432. [CrossRef]

93. Castelnovo, W.; Misuraca, G.; Savoldelli, A. Smart cities governance: The need for a holistic approach to assessing urban participatory policy making. Soc. Sci. Comput. Rev. 2016, 34, 724-739. [CrossRef]

94. Wilson, B.; Chakraborty, A. Planning Smart(er) Cities: The Promise of Civic Technology. J. Urban Technol. 2019, 26, 29-51. [CrossRef]

95. Caprotti, F.; Springer, C.; Harmer, N. 'Eco' For Whom? Envisioning Eco-urbanism in the Sino-Singapore Tianjin Eco-city, China. Int. J. Urban Reg. Res. 2015, 39, 495-517. [CrossRef]

96. Breuer, J.; Pierson, J. The right to the city and data protection: Complementary for developing citizen-centric digital cities. Inf. Commun. Soc. 2021, 24, 797-812. [CrossRef]

97. Gjermundrød, H.; Dionysiou, I. A conceptual framework for configurable privacy-awareness in a citizen-centric eGovernment. Electron. Gov. Int. J. 2015, 11, 258. [CrossRef]

98. Banisar, D. The Right to Information and Privacy: Balancing Rights and Managing Conflicts; The World Bank: Washington, DC, USA, 2011.

99. Nautiyal, L.; Malik, P.; Agarwal, A. Cybersecurity System: An Essential Pillar of Smart Cities. In Smart Cities, Computer Communications and Networks; Mahmood, Z., Ed.; Springer: Cham, Switzerland, 2018; pp. 25-50.

100. Goodwin, C.F.; Nicholas, J.P. Developing a City Strategy for Cybersecurity: A Seven-Step Guide for Local Governments; Microsoft: Washington, DC, USA, 2014.

101. Ma, H.D. Internet of Things: Objectives and Scientific Challenges. J. Comput. Sci. Technol. 2011, 26, 919-924. [CrossRef]

102. Nick, G. How Many IoT Devices Are There in 2021? Available online: https://techjury.net/blog/how-many-iot-devices-arethere/\#gref (accessed on 27 July 2021).

103. Devanesan, J. Cybersecurity Is Top Concern, as Online Threats Mount in Malaysia by 82.5\%. Available online: https: / techwireasia. com/2020/04/cybersecurity-is-top-concern-as-online-threats-mount-in-malaysia-by-82-5/ (accessed on 27 July 2021).

104. Yun, T.Z. Moving beyond Awareness to Adoption of IoT. Available online: https://www.theedgemarkets.com/article/coverstory-moving-beyond-awareness-adoption-iot (accessed on 27 July 2021).

105. Jones, H.; Twiss, B.L. Forecasting Technology for Planning Decisions; Macmillan: New York, NY, USA, 1978.

106. Jamil, M.R.M.; Noh, N.M. Kepelbagaian Metodologi Dalam Penyelidikan: Rekab Bentuk dan Pembangunan; Qaisar Prestige Resources: Shah Alam, Malaysia, 2020.

107. Embong, A.R. State-Led Modernization and the New Middle Class in Malaysia; Palgrave: New York, NY, USA, 2002.

108. Dalkey, N.; Helmer, O. An Experimental Application of the DELPHI Method to the Use of Experts. Manag. Sci. 1963, 9, 458-467. [CrossRef]

109. Lateh, N.; Yaacob, S.E.; Md Rejab, S.N. Applying the fuzzy delphi method (FDM) to analyze the expert consensus values for instrument of shariah-compliant gold investment. Pertanika J. Soc. Sci. Humanit. 2017, 25, 165-178.

110. Ulschak, F. Human Resource Development: The Theory and Practice of Need Assessment; Reston Publishing Company: Reston, VA, USA, 1983.

111. Grime, M.M.; Wright, G. Delphi Method. In Wiley StatsRef Statistics Reference Online; Balakrishnan, N., Colton, T., Everitt, B., Piegorsch, W., Ruggeri, F., Teugels, J.L., Eds.; Wiley: Hoboken, NJ, USA, 2016; pp. 1-6.

112. Cheng, C.-H.; Lin, Y. Evaluating the best main battle tank using fuzzy decision theory with linguistic criteria evaluation. Eur. J. Oper. Res. 2002, 142, 174-186. [CrossRef]

113. Chu, H.-C.; Hwang, G.-J. A Delphi-based approach to developing expert systems with the cooperation of multiple experts. Expert Syst. Appl. 2008, 34, 2826-2840. [CrossRef]

114. Murry, J.W.; Hammons, J.O. Delphi: A Versatile Methodology for Conducting Qualitative Research. Rev. High. Educ. 1995, 18, 423-436. [CrossRef]

115. Tang, C.-W.; Wu, C.-T. Obtaining a picture of undergraduate education quality: A voice from inside the university. High. Educ. 2010, 60, 269-286. [CrossRef]

116. Esmaeilpoorarabi, N.; Yigitcanlar, T.; Guaralda, M.; Kamruzzaman, M. Evaluating place quality in innovation districts: A Delphic hierarchy process approach. Land Use Policy 2018, 76, 471-486. [CrossRef]

117. Perveen, S.; Kamruzzaman, M.; Yigitcanlar, T. Developing policy scenarios for sustainable urban growth management: A Delphi approach. Sustainability 2017, 9, 1787. [CrossRef]

118. Sulaiman, H.F.; Ismail, R.; Yusoff, H.M.; Anuar, N.; Jamil, M.R.M.; Daud, F. Validation of occupational zoonotic disease questionnaire using fuzzy Delphi method. J. Agromed. 2020, 25, 166-172. [CrossRef] [PubMed]

119. Drabble, J. The Economic History of Malaysia. Available online: http://eh.net/encyclopedia/economic-history-of-malaysia/ (accessed on 24 July 2021).

120. Mat Arisah, F.; Zainal Badari, S.A.; Hashim, A.H. Amalan pembelian secara atas talian dan faktor-faktor mempengaruhi. Malays. J. Soc. Sci. Humanit. 2016, 1, 111-123.

121. Lim, S.B.; Malek, J.A.; Kong, Y.C.; Tahir, Z.; Hernowo, B. Lessons from differences in the global and local discourse views on the safe city status of Kuala Lumpur, Malaysia. Geogr. Malays. J. Soc. Sp. 2021, 17, 143-158.

122. Malek, J.A.; Lim, S.B.; Tahir, Z. Understanding the issues of citizen participation. J. Nusant. Stud. 2019, 4, 1-22. [CrossRef] 
123. Aziz, S.A. Maqasid Al-Syariah dalam perlembagaan persekutuan: Suatu perbahasan awal. Kanun J. Undang. Malays. 2016, 28, 278-312.

124. Lim, S.B.; Malek, J.A.; Mohd Yusof, H.; Tahir, Z. Malaysia Smart City Framework: A trusted framework for shaping smart Malaysian citizenship? In Handbook of Smart Cities; Augusto, J.C., Ed.; Springer: Cham, Switzerland, 2021; pp. 515-538.

125. Economist Intelligence Unit (EIU). Democracy Index 2020: In Sickness and in Health? Economist Intelligence Unit: London, UK, 2020.

126. Araya, D. (Ed.) Smart Cities as Democratic Ecologies; Palgrave Macmillan: New York, NY, USA; London, UK, 2015.

127. Lim, S.; Malek, J.; Yigitcanlar, T. Post-Materialist Values of Smart City Societies: International Comparison of Public Values for Good Enough Governance. Future Internet 2021, 13, 201. [CrossRef]

128. Majid, N.A. 150 Electric Buses for Putrajaya by 2025. Available online: https://www.nst.com.my/news/nation/2017/10/290305 /150-electric-buses-putrajaya-2025 (accessed on 25 July 2021).

129. Teoh, L.E.; Khoo, H.L.; Goh, S.Y.; Chong, L.M. Scenario-based electric bus operation: A case study of Putrajaya, Malaysia. Int. J. Transp. Sci. Technol. 2018, 7, 10-25. [CrossRef]

130. Alias, W.N.H.W. Bas Awam Putrajaya Tersadai, “Merangkak”. Available online: https://www.bharian.com.my/berita/nasional/ 2018/08/460658/bas-awam-putrajaya-tersadai-merangkak (accessed on 25 July 2017).

131. Mustapa, S.; Ayodele, B.; Ishak, W.M.; Ayodele, F. Evaluation of Cost Competitiveness of Electric Vehicles in Malaysia Using Life Cycle Cost Analysis Approach. Sustainability 2020, 12, 5303. [CrossRef]

132. MITI. National Automotive Policy 2020; Ministry of International Trade and Industry: Putrajaya, Malaysia, 2020.

133. Culpan, T. A Quiet Leader: Why Malaysia Ranks High in Global List of Cybersecurity. Available online: https: / / www.business-standard.com/article/international/malaysia-among-top-ten-countries-in-cybersecurity-due-to-globalcooperation-121070200403_1.html (accessed on 27 July 2021).

134. MCMC. National Digital Infrastructure Lab (NDIL). Report 3 September 2020; Malaysian Communications and Multimedia Commission: Putrajaya, Malaysia, 2020.

135. Yigitcanlar, T.; Sarimin, M. Multimedia super corridor, Malaysia: Knowledge-based urban development lessons from an emerging economy. Vine 2015, 45, 126-147. [CrossRef]

136. Yigitcanlar, T.; Sarimin, M. The Role of Universities in Building Prosperous Knowledge Cities: The Malaysian Experience. Built Environ. 2011, 37, 260-280. [CrossRef]

137. Yigitcanlar, T.; Dur, F. Making space and place for knowledge communities: Lessons for Australian practice. Australas. J. Reg. Stud. 2013, 19, 36-63.

138. Perveen., S.; Kamruzzaman, M.; Yigitcanlar, T. What to assess to model the transport impacts of urban growth? A Delphi approach to examine the space-time suitability of transport indicators. Int. J. Sustain. Transp. 2019, 13, 597-613. [CrossRef]

139. Siokas, G.; Tsakanikas, A.; Siokas, E. Implementing smart city strategies in Greece: Appetite for success. Cities 2021, $108,102938$. [CrossRef] 